University of South Florida

DIGITAL COMMONS @ UNIVERSITY OF SOUTH FLORIDA
Digital Commons @ University of South Florida

4-1-2013

\title{
Quantifying the Benefits of the Florida Transit Research Inspection Procurement Services (TRIPS) Program
}

CUTR

Follow this and additional works at: https://digitalcommons.usf.edu/cutr_nctr

\section{Recommended Citation}

"Quantifying the Benefits of the Florida Transit Research Inspection Procurement Services (TRIPS) Program," National Center for Transit Research (NCTR) Report No. CUTR-NCTR-RR-2011-05, Center for Urban Transportation Research, University of South Florida, 2013.

DOI: https://doi.org/10.5038/CUTR-NCTR-RR-2011-05

Available at: https://scholarcommons.usf.edu/cutr_nctr/107

This Technical Report is brought to you for free and open access by the National Center for Transit Research (NCTR) Archive (2000-2020) at Digital Commons @ University of South Florida. It has been accepted for inclusion in Research Reports by an authorized administrator of Digital Commons @ University of South Florida. For more information, please contact digitalcommons@usf.edu. 

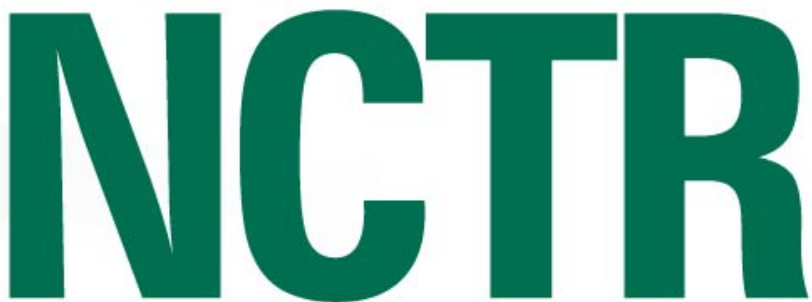

NATIONAL CENTER for TRANSIT RESEARCH

\section{Quantifying the Benefits of the Florida Transit Research Inspection Procurement Services (TRIPS) Program}

April 2013

PROJECT NO. FDOT BDK85 Task Work Order \#977-31

PREPARED FOR Florida Department of Transportation

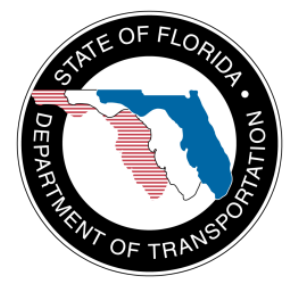




\section{Quantifying the Benefits of the Florida Transit Research Inspection Procurement Services (TRIPS) Program}

FDOT BDK85 Task Work Order \#977-31

\section{Prepared for:}

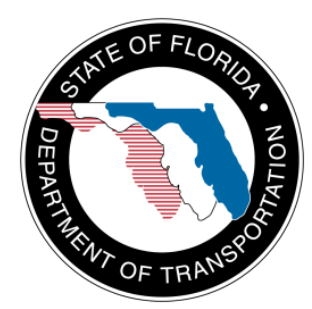

Florida Department of Transportation Erin Schepers, Project Manager

Prepared by:

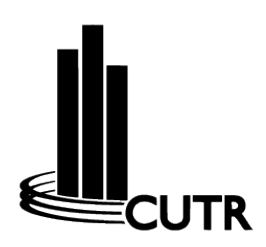

USF Center for Urban Transportation Research

Stephen L. Reich, Associate in Research

Final Report

April 2013 


\section{Disclaimer}

The contents of this report reflect the views of the authors, who are responsible for the facts and the accuracy of the information presented herein. This document is disseminated under the sponsorship of the U.S. Department of Transportation University Transportation Centers Program and the Florida Department of Transportation in the interest of information exchange. The U.S. Government and the Florida DOT assume no liability for the contents or use thereof. 


\section{Technical Report Documentation}

\begin{tabular}{|c|c|c|c|}
\hline $\begin{array}{l}\text { 1. Report No. } \\
\text { BDK85 } 977-31\end{array}$ & \multicolumn{2}{|c|}{ 2. Government Accession No. } & 3. Recipient's Catalog No. \\
\hline \multicolumn{3}{|c|}{$\begin{array}{l}\text { Quantifying the Benefits of the Florida Transit Research Insp } \\
\text { Services (TRIPS) Program }\end{array}$} & $\begin{array}{l}\text { 5. Report Date } \\
\text { April } 2013\end{array}$ \\
\hline \multicolumn{4}{|c|}{ 6. Performing Organization Code } \\
\hline \multicolumn{2}{|c|}{$\begin{array}{l}\text { 7. Author(s) } \\
\text { Stephen L. Reich, Janet L. Davis }\end{array}$} & \multicolumn{2}{|c|}{$\begin{array}{l}\text { 8. Performing Organization Report No. } \\
\text { NCTR 77936-00/BDK85 977-31 } \\
\text { U.S. DOT DTRGS98-G-0032 }\end{array}$} \\
\hline \multicolumn{2}{|c|}{$\begin{array}{l}\text { 9. Performing Organization Name and Address } \\
\text { National Center for Transit Research } \\
\text { Center for Urban Transportation Research (CUTR) } \\
\text { University of South Florida } \\
4202 \text { East Fowler Avenue, CUT100 } \\
\text { Tampa, FL 33620-5375 }\end{array}$} & \multicolumn{2}{|c|}{ 10. Work Unit No. (TRAIS) } \\
\hline \multicolumn{4}{|c|}{$\begin{array}{l}\text { 11. Contract or Grant No. } \\
\text { FDOT BDK85 } 977-31\end{array}$} \\
\hline \multicolumn{2}{|c|}{$\begin{array}{l}\text { 12. Sponsoring Agency Name and Address } \\
\text { Florida Department of Transportation } \\
605 \text { Suwannee Street, MS } 30 \\
\text { Tallahassee, FL 32399-0450 } \\
\text { Research and Innovative Technology Administration } \\
\text { U.S. Department of Transportation } \\
\text { Mail Code RDT-30 } \\
1200 \text { New Jersey Ave. SE, Room E33 } \\
\text { Washington, D.C. } 20590-0001\end{array}$} & \multicolumn{2}{|c|}{$\begin{array}{l}\text { 13. Type of Report and Period Covered } \\
\text { Final Report } 07 / 01 / 12-4 / 30 / 13\end{array}$} \\
\hline \multicolumn{4}{|c|}{ 14. Sponsoring Agency Code } \\
\hline \multicolumn{4}{|c|}{$\begin{array}{l}\text { 15. Supplementary Notes } \\
\text { FDOT Project Manager: Erin Schepers }\end{array}$} \\
\hline \multicolumn{4}{|l|}{ 16. Abstract } \\
\hline \multicolumn{4}{|c|}{$\begin{array}{l}\text { This study details the analysis of the Florida Transit Research Inspection Procurement Services (TRIPS) Program. It } \\
\text { provides a comparative assessment of the program with respect to out-of-state practice, provides recommendations to } \\
\text { improve life cycle vehicle data reporting procedures and details benefits of the program. The collection of this } \\
\text { information can be used to compare TRIPS vehicle performance with vehicles purchased by transit agencies by other } \\
\text { means, or to compare TRIPS vehicles with similar vehicle fleets in sample out-of-state locations. }\end{array}$} \\
\hline \multicolumn{2}{|c|}{$\begin{array}{l}\text { 17. Key Words } \\
\text { TRIPS program, vehicle procurement, transit program } \\
\text { evaluation }\end{array}$} & \multicolumn{2}{|c|}{$\begin{array}{l}\text { 18. Distribution Statement } \\
\text { No restrictions }\end{array}$} \\
\hline $\begin{array}{l}\text { 19. Security Classification } \\
\text { (of this report) } \\
\text { Unclassified }\end{array}$ & $\begin{array}{l}\text { 20. Security Classification } \\
\text { (of this page) } \\
\text { Unclassified } \\
\end{array}$ & $\begin{array}{r}\text { 21. No. of Pages } \\
69\end{array}$ & 22. Price \\
\hline
\end{tabular}




\section{Metric Conversion}

\begin{tabular}{|c|c|c|c|c|}
\hline SYMBOL & WHEN YOU KNOW & MULTIPLY BY & TO FIND & SYMBOL \\
\hline \multicolumn{5}{|c|}{ LENGTH } \\
\hline in & inches & 25.4 & millimeters & $\mathrm{mm}$ \\
\hline ft & feet & 0.305 & meters & $\mathrm{m}$ \\
\hline yd & yards & 0.914 & meters & $\mathrm{m}$ \\
\hline mi & miles & 1.61 & kilometers & $\mathrm{km}$ \\
\hline \multicolumn{5}{|c|}{ VOLUME } \\
\hline fl oz & fluid ounces & 29.57 & milliliters & $\mathrm{mL}$ \\
\hline gal & gallons & 3.785 & liters & L \\
\hline $\mathrm{ft}^{3}$ & cubic feet & 0.028 & cubic meters & $\mathrm{m}^{3}$ \\
\hline$y d^{3}$ & cubic yards & 0.765 & cubic meters & $\mathrm{m}^{3}$ \\
\hline \multicolumn{5}{|c|}{ NOTE: Volumes greater than $1000 \mathrm{~L}$ shall be shown in $\mathrm{m}^{3}$} \\
\hline \multicolumn{5}{|c|}{ MASS } \\
\hline $\mathbf{o z}$ & ounces & 28.35 & grams & $\mathrm{g}$ \\
\hline lb & pounds & 0.454 & kilograms & $\mathrm{kg}$ \\
\hline $\mathbf{T}$ & short tons $(2000 \mathrm{lb})$ & 0.907 & $\begin{array}{c}\text { megagrams } \\
\text { (or "metric ton") }\end{array}$ & Mg (or "t") \\
\hline \multicolumn{5}{|c|}{ TEMPERATURE (exact degrees) } \\
\hline${ }^{\circ} \mathbf{F}$ & Fahrenheit & $\begin{array}{c}5(F-32) / 9 \\
\text { or }(F-32) / 1.8\end{array}$ & Celsius & ${ }^{\circ} \mathrm{C}$ \\
\hline
\end{tabular}




\section{Acknowledgments}

Contributions and assistance during the project on the part of Lisa Staes, director, Transit Technical Assistance \& Training Program at the Center for Urban Transportation Research, staff members Cindy Wooten in the area of Section 5310 grant funds and Deborah Sapper on the subject of the TRIPS database, and those local agencies that participated in the survey were greatly appreciated. TRIPS Program Manager Edward Bart contributed to the final version of the report and provided assistance in the identification of the program benefits. 


\section{Executive Summary}

Since 1995, the Florida Transit Research Inspection Procurement Services (TRIPS) Program, formerly known as the Florida Vehicle Procurement Program (FVPP), has been providing government and nonprofit agencies with the means of procuring quality public transportation vehicles at competitive prices. Through TRIPS, Florida's public and private nonprofit transportation agencies can procure well-equipped, well-built transit vehicles at a reduced cost by means of centrally administered statewide contracts for vehicle procurement. The program ensures that vehicle procurements adhere to and are consistent with all applicable federal, state, and Florida Department of Transportation (FDOT) guidelines, requirements, industry standards, and certifications, as well as the Federal Transit Administration's (FTA) Best Practices Procurement Manual. The vehicle manufacturer's compliance with technical specifications is continually monitored by contracted line inspectors at each vehicle production site and at an FDOT vehicle inspection facility located in Tallahassee, Florida.

With the volume of vehicles purchased through contracts established by TRIPS, transit agencies can take advantage of longer warranty periods, extended service after the sale, and training opportunities offered by both the vehicle dealers and component manufacturers. The TRIPS program is administered by the Center for Urban Transportation Research (CUTR) under an agreement with FDOT.

At the outset of this study, CUTR researchers had intended to attempt to perform a life cycle cost analysis on TRIPS vehicles. Other costs and benefits were then to be identified and comparisons made with similar vehicles not procured through the TRIPS program. This approach was not able to be realized and comparable costs and metrics were developed in order to assess the benefits and costs.

Using data from the TRIPS database, the American Public Transportation Association (APTA) 2011 Vehicle Report and the Federal Transit Administration's National Transit Database (NTD) for 2011, comparable vehicles were used to compare to those in service in Florida. Because of the varying reporting requirements, particularly for smaller agencies employing TRIPS vehicles, data on "demand response" vehicles were used extensively. Where vehicle size was identified, comparisons were made to like vehicles.

The span of time used in this report (the study period) was from 2007 through 2011. During that time, the TRIPS program handled over $\$ 100$ million in transit vehicle purchases and, on average, the vehicles purchased through the TRIPS program were $\$ 1,275$ less expensive than similar vehicles nationally. This lower cost of acquisition for the majority of the vehicles purchased translates into more than $\$ 204,000$ in savings per year at current vehicle purchase rates.

For TRIPS vehicles purchased with the assistance of federal Section 5310 funding, the average cost per vehicle declined from 2007 to 2011. The majority of these purchase orders were for "Cutaway" or "Standard Cutaway" vehicles and acquisition costs decreased from the $\$ 70,000$ to $\$ 80,000$ range in 2007 and 2008 to less than $\$ 64,000$ by 2011 . 
Since 2007, the average cost to repair collision damage for a demand response vehicle in Florida has been lower than the national average. During the study period, Florida's collision costs were approximately $\$ 600$ lower for each incident. This may not be solely due to increased vehicle integrity afforded by the stringent TRIPS vehicle safety specifications; however, the data show lower repair costs that translate into an annualized cost avoided of $\$ 23,262.52$.

Passenger injury rates were lower for Florida's demand response service vehicles (a subset of the TRIPS vehicles) than the national rates based on the NTD. The injury rate was on average 16.53 percent lower for passengers in Florida than for the U.S. for the study period. Using National Highway Traffic Safety Administration (NHTSA) estimates for the cost per injury, an annual cost avoidance of $\$ 797,237$ was calculated.

The availability of procuring vehicles through the TRIPS program relieves small and large agencies of the administrative burdens required in the development of technical specifications and competitive procurement practices. The program provides them with the opportunity to take advantage of TRIPS contracts that incorporate sound technical and safety specifications, enhanced vehicle inspection practices, mandated dealer coordination, training, technical assistance, and extended warranties.

A review of five FDOT district inspection reports revealed that 34 percent of the TRIPS fleet has been in service for more than five years and 3.3 percent of the vehicles had recorded mileage in excess of 150,000 miles. These findings indicate that in terms of performance data, the vehicles show extensive service well beyond their projected useful life. In addition, a comparison with other states' useful life requirement for vehicles purchased with Section 5310 funds shows that Florida's TRIPS vehicles are required to achieve a longer useful life than vehicles in other states.

The program costs for CUTR to manage and operate the TRIPS program have been stable at $\$ 540,000$ per year, with the exception of an additional $\$ 175,000$ in grants in Fiscal Year (FY) 2009-2010 and FY 2010-2011 because of the increased activity resulting from American Recovery and Reinvestment Act (ARRA) funding. The average cost to FDOT for the 2007 through 2011 study period was $\$ 586,000$, translating into a cost per unit of $\$ 2,395.75$, or 3.25 percent of the average vehicle cost for all vehicles reported in the Purchase Order database.

Florida is one of only 16 states that provides subrecipients with a reduced local match $(10 \%)$ for the purchase of transit vehicles under the Section 5310 program, and appears to be the only state that requires a second level of safety testing for compliance with established FDOT Crash and Safety Testing Standards.

Adding all of the calculated costs avoided based on the performance of demand response vehicles in Florida along with their safety record and acquisition costs, and deducting the program administrative costs, yields an estimated $\$ 408,000$ net annual benefit to the state. 
Routine, periodic reporting of maintenance and operating data on TRIPS vehicles and enhancements to the TRIPS database would facilitate a more robust basis for any future cost comparisons. 


\section{Table of Contents}

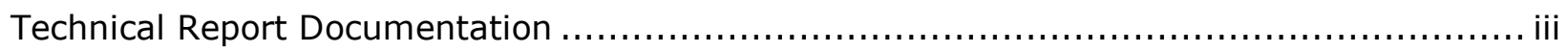

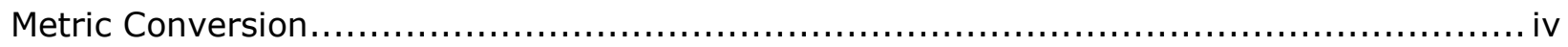

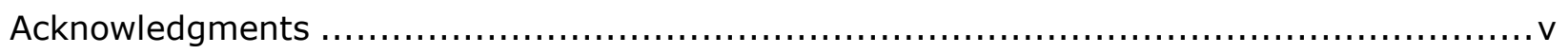

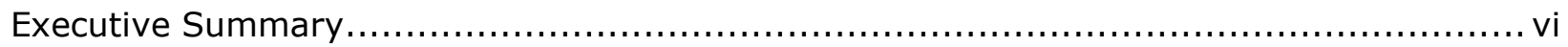

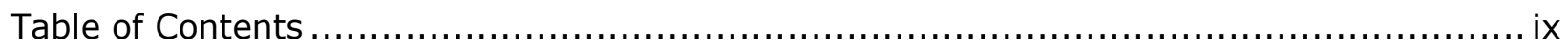

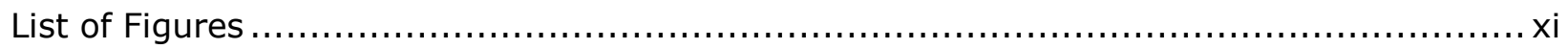

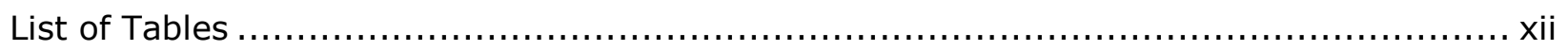

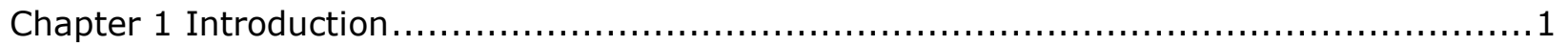

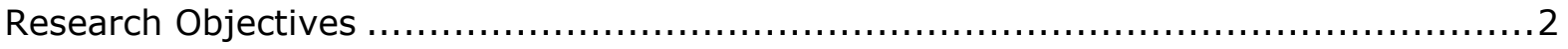

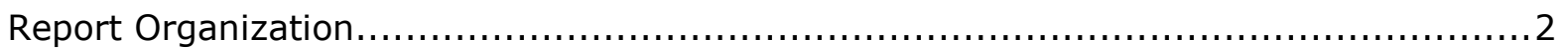

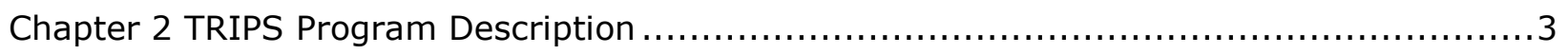

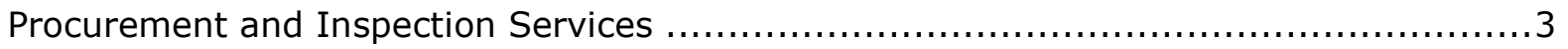

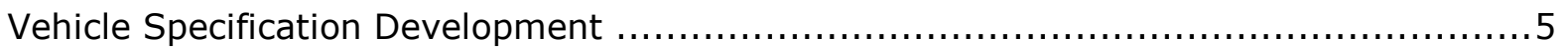

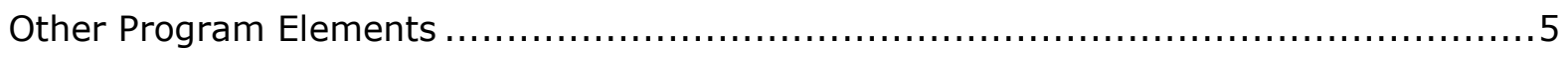

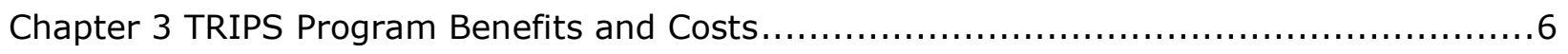

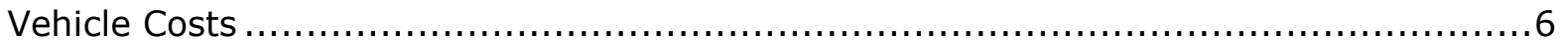

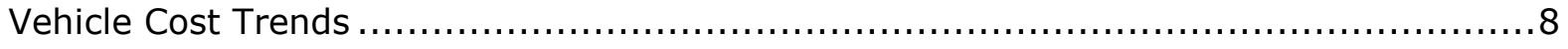

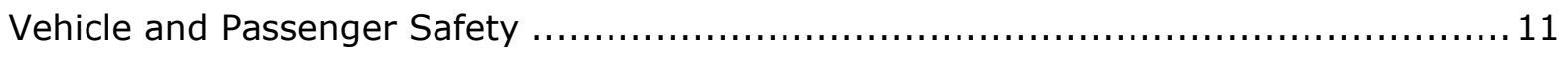

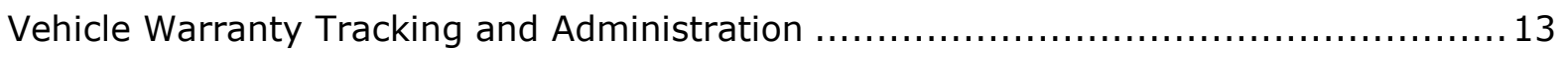

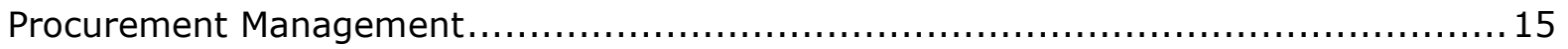

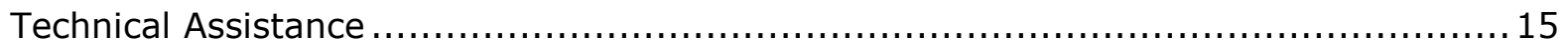

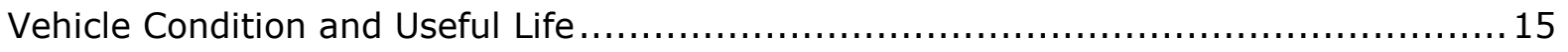

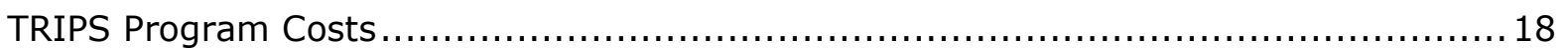

TRIPS Program Benefits and Cost Findings ............................................. 20

Chapter 4 Section 5310 Practices throughout the U.S. ...................................... 22

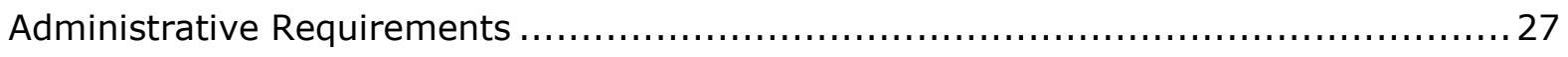

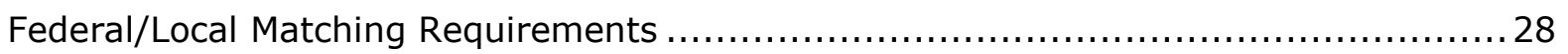

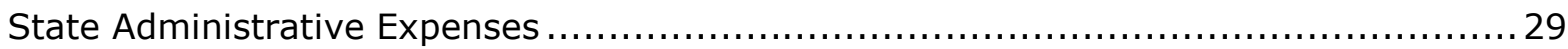

Vehicle Useful Life and Replacement Standards .......................................... 30

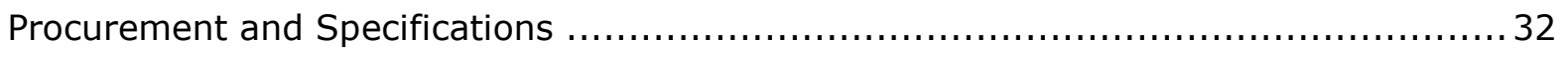

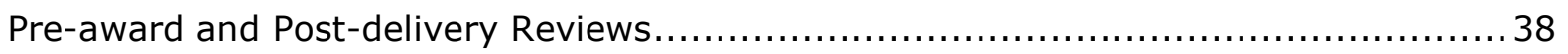

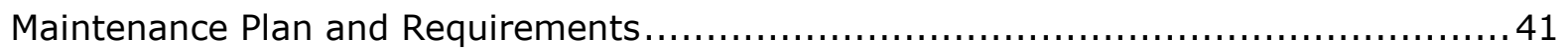

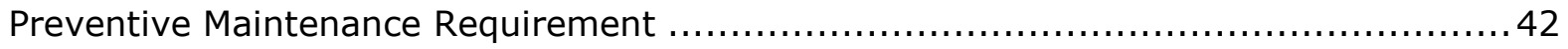

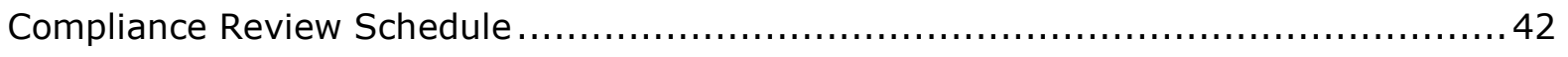

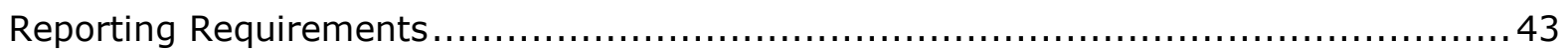




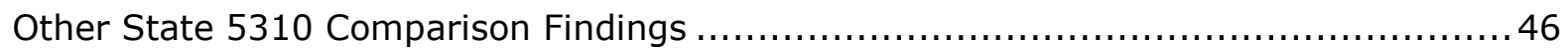

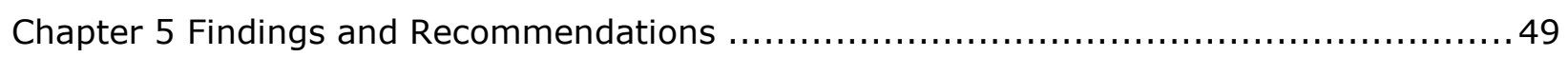

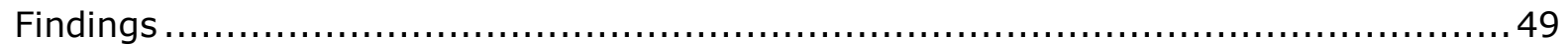

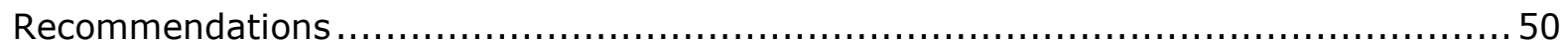

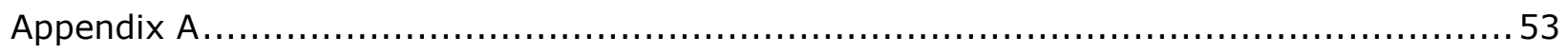

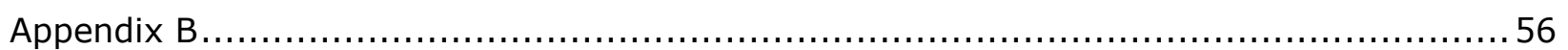




\section{List of Figures}

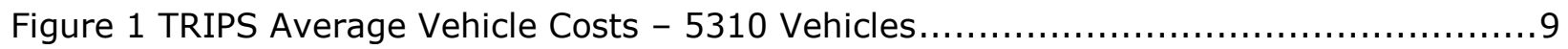

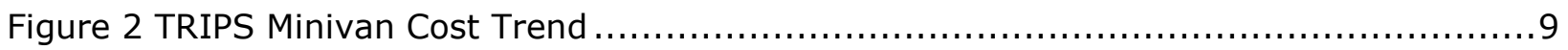

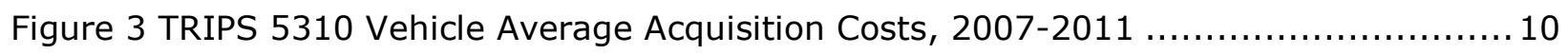

Figure 4 TRIPS Non-5310 Vehicle Average Acquisition Costs, $2007-2011 \ldots \ldots \ldots \ldots \ldots \ldots \ldots$

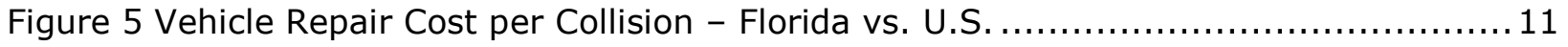

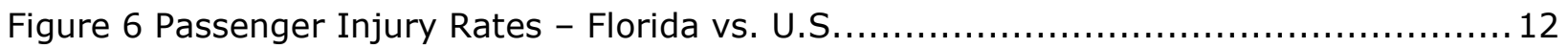

Figure 7 Annual FDOT Funding of TRIPS - CUTR 2007-2011 ............................ 19

Figure 8 TRIPS Inspection Agency Webpage Overview ................................. 51

Figure 9 Recommended Modifications to Transit Agency TRIPS Webpage $\ldots \ldots \ldots \ldots \ldots \ldots \ldots \ldots 2$ 


\section{List of Tables}

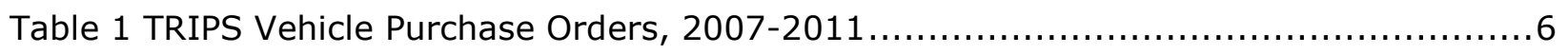

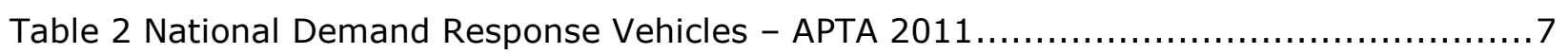

Table 3 APTA Vehicle Costs -2010 and 2011 Acquisitions ..............................

Table 4 Small Vehicle Purchase Cost Comparison - FL vs. U.S., 2010 \& $2011 \ldots \ldots \ldots \ldots \ldots \ldots . . . . . .8$

Table 5 DR Passenger Injury Rates per One Million PMT - FL vs. U.S., 2006-2011 ........... 13

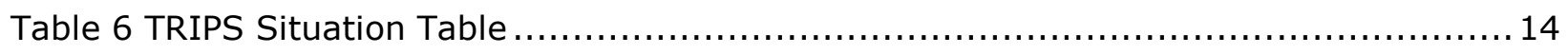

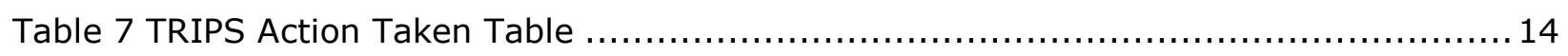

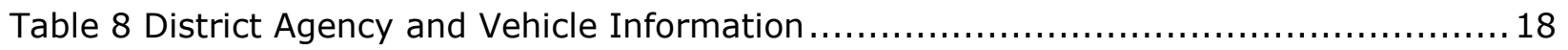

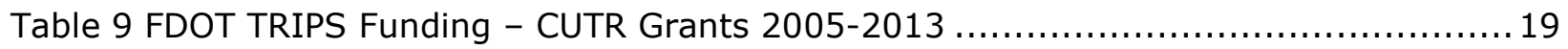

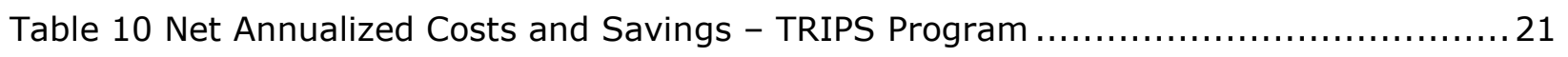

Table 11 State Management Plan vs. Application Manual ................................. 25

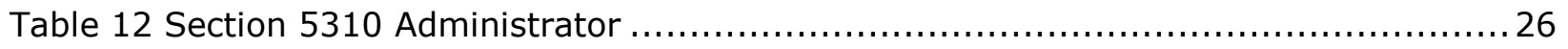

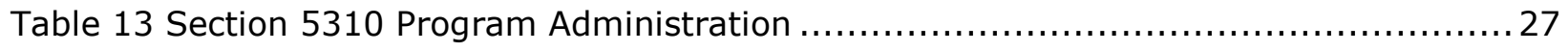

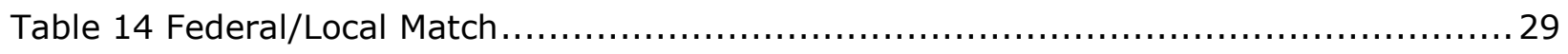

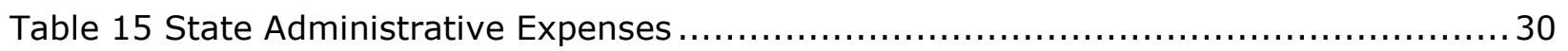

Table 16 Vehicle Useful Life Years/Mileage.............................................. 31

Table 17 Section 5310 Responsibility for Procurement and Specifications ...................... 33

Table 18 Pre-Award and Post-Delivery Audits............................................... 41

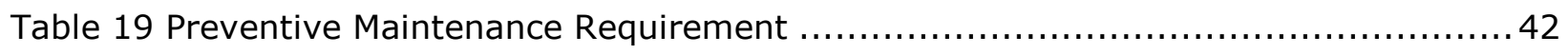

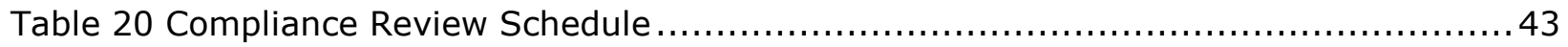

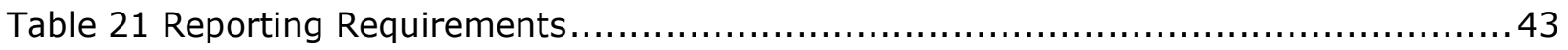




\section{Chapter 1 Introduction}

Since 1995, the Florida Transit Research Inspection Procurement Services Program, formerly known as the Florida Vehicle Procurement Program, has been providing government and nonprofit agencies with the means of procuring quality public transportation vehicles at competitive prices. Through TRIPS, Florida's public and private nonprofit transportation agencies can procure well-equipped, well-built transit vehicles at a reduced cost by means of centrally administered statewide contracts for vehicle procurement. The program ensures that vehicle procurements adhere to and are consistent with all applicable federal, state, and FDOT guidelines, requirements, industry standards, and certifications, as well as the FTA's Best Practices Procurement Manual. The vehicle manufacturer's compliance with technical specifications is continually monitored by contracted line inspectors at each vehicle production site and at an FDOT vehicle inspection facility located in Tallahassee, Florida. With the volume of vehicles purchased through contracts established by TRIPS, transit agencies can take advantage of longer warranty periods, extended service after the sale, and training opportunities offered by both the vehicle dealers and component manufacturers. The TRIPS program is administered by CUTR under an agreement with FDOT.

In 1999, CUTR examined savings over the first three years of FDOT's FVPP to study the impact of purchasing pools on vehicle price. CUTR found that through a pooled procurement in 1996 and a contract centrally procured by the state in 1997 and 1998, 440 vehicles were purchased at a cost of $\$ 17.3$ million, with an estimated minimum cost savings of $\$ 4.1$ million in initial pricing, administration time, and warranty enforcement. ${ }^{1} A$ vehicle purchase cost comparison was done for vehicles acquired under the FVPP versus those that were not, but the analysis focused only on acquisition costs.

It is recognized that although buying vehicles in quantity can produce scale economies and reduce bulk acquisition costs, there are other potential savings related to the TRIPS program. Specifically, vehicles purchased under the TRIPS program must meet strict safety standards that are unique to Florida, which result in structural improvements to the integrity of the purchased vehicles. This results in vehicle improvements that might prolong the average life of each unit, lower recurring costs, and reduce passenger injuries in vehicle crashes. In addition, under the TRIPS program, vehicle procurement warranties tend to exceed minimum requirements usually provided through competitive bidding, which could have a positive impact on investment return. Therefore, to capture as many benefits as possible associated with the uniqueness of the TRIPS program, a broader analysis that focuses on a wider array of benefits is warranted in combination with a review of other state vehicle procurement programs administered through Section 5310 grant funds to explore commonalities and unique characteristics.

${ }^{1}$ Center for Urban Transportation Research, "Florida Vehicle Procurement Program Economic Benefits Report" (Prepared for the Florida DOT), Tampa: University of South Florida, 1999. 


\section{Research Objectives}

The objective of this research project is to identify and document monetary benefits of Florida's TRIPS program, to compare vehicle procurement practices in other states, and to determine the benefits, including economic, derived from the TRIPS program. The focus of the research is on the full range of benefits related to vehicle purchase and maintenance to uncover any long-term advantages associated with agency administration, regulatory compliance, warranty monitoring, and vehicle inspection.

\section{Report Organization}

Chapter 2 presents an overview of the TRIPS program. Chapter 3 examines the programmatic costs and the benefits that were estimated in the study. Chapter 4 includes an analysis of out-of-state experiences that compares how similar Section 5310 programs are currently operating. Chapter 5 concludes with a summary of findings and provides suggestions for future procedures to gather data to assist in the ongoing evaluation of the program. 


\section{Chapter 2 \\ TRIPS Program Description}

Florida's TRIPS program provides both public and private nonprofit transportation agencies with well-built transit vehicles at a reduced cost. Through centrally administered statewide contracts for procurement, the program ensures that vehicles adhere to all applicable federal, state, and FDOT guidelines and requirements. During production, the vehicles are monitored by contracted line inspectors to ensure the manufacturer's compliance with technical specifications. The FDOT inspection facility also provides technical assistance on fleet issues and undiagnosed problems. Through TRIPS, transit agencies benefit from longer warranty periods, extended service after the sale, and training opportunities.

\section{Procurement and Inspection Services}

The TRIPS program establishes statewide purchasing agreements between Florida transit agencies and dealers for the acquisition of equipment as detailed in competitively bid contracts. Following award of the initial model production year, the TRIPS program has an option to extend the purchasing agreement for four additional model production years subject to the same pricing, terms, and conditions of the original agreement, except when a model-year change is specific to the automotive or bus industry. Any adjustments in chassis model prices and second-stage production costs are contingent upon certification of the increase from the manufacturer and approval by the TRIPS program administrator. Acceptance in writing by the transit agency of the dealer's offer to furnish units as specified constitutes a contract between the dealer and the transit agency, and falls outside of the responsibility of TRIPS and FDOT.

The transit agency must provide the dealer with properly completed forms and order information, resolve issues related to late penalties liquidated damages, and adhere to the terms and conditions regarding final acceptance and terms of payment as delineated in the purchasing agreement.

FDOT and TRIPS are responsible to oversee the proper use of federal and state grant monies, ensure that all federal, state, and purchasing agreement requirements and certifications are met, monitor warranty and dealer services, conduct production-line and/or contractor inspections, and intercede on behalf of the transit agencies.

Since new vehicles may contain components that are unfamiliar to purchasers' maintenance and operating personnel, training requirements are integral components of the purchasing agreements. Each agreement specifies minimum training requirements that TRIPS expects purchasers to receive by qualified instructors. Training requirements for the recent Contract \#TRIPS-11-CA-TP for Champion Cutaway Transit Vehicles included the following:

- Driver/Maintenance Orientation - four hours @ five locations annually

- Air Conditioning/Certification - four hours @ five locations annually

- Securement Device/Certification - four hours @ five locations annually

- Electrical \& Electronics Familiarization - four hours @ five locations annually 
- Wheelchair Lift Training - four hours @ five locations annually

The agency contacts the dealer directly to place an order and works closely with the dealer to select floor plans, seating selections, paint schemes, and any special options or conditions that impact the final order and purchase price. For vehicles not funded by the FTA Section 5310 grant program, the agency deals directly with the dealer. For all vehicles funded through the FTA Section 5310 grant program, a copy of the completed order form and either an agency purchase order (PO) or a check for the agency's portion payable to the contractor must be delivered to the CUTR Section 5310 program coordinator, who verifies the order accuracy, completes the request for the FDOT share, and forwards the request to Tallahassee for the FDOT PO. When the FDOT PO number is assigned, the TRIPS Section 5310 program coordinator places the order with the contractor/dealer and notifies the agency of its status.

The contractor provides written confirmation to the agency and/or CUTR of receipt of the order within 72 hours of receiving the order with PO. At a minimum, acknowledgement of the order contains:

- Agency's purchase order number

- Date order was received

- Date order was placed with manufacturer

- Production and VIN numbers when available

- Estimated delivery date

CUTR maintains the TRIPS vehicle database (called the Data Center), which stores information on vehicles purchased under the program. The database was developed under the former FVPP and was conceived as a means to integrate information between agencies, dealers, manufacturers, inspection agencies, and FDOT. To ensure privacy, each entity is provided a username and password to navigate through stored information. The data for the vehicles procured through the program can be entered and retrieved using the website. The database is dynamically updated upon entering new data, which can be immediately retrieved.

Completed units must be delivered to the agency within an amount of time specified in the contract. In the case of Contract \#TRIPS-11-CA-TP for Champion Cutaway Transit Vehicles, delivery must occur within 90 days from receipt of chassis or purchase order, whichever occurs last. In the event of delay in completion of the delivery of vehicles beyond the date specified in the contract, in addition to any granted extensions agreed to in writing by the agency, the agency may assess as liquidated damages $\$ 25.00$ per calendar day per vehicle.

Each vehicle purchased through TRIPS must be routed to FDOT's Springhill Inspection Facility for an inspection prior to delivery to the dealer. The dealer must enter all vehicle data into the TRIPS database prior to delivery for inspection. Inspection agencies can view inspection forms, run inspection reports on single vehicles, or pull out information on the entire database. Any issue encountered during the pre-delivery inspection must be addressed before the vehicle is accepted by the receiving transportation agency. The dealer 
must correct all noted write-ups prior to delivery of the vehicle to the procuring agency. The TRIPS inspection in no way relieves the dealer from the required pre-delivery inspection (PDI). After delivery of the vehicle, the dealer must report warranty issues and identify actions taken to resolve these issues throughout the entire warranty period.

\section{Vehicle Specification Development}

The TRIPS Technical Committee, under the direction of the TRIPS manager, is responsible for the development and revision of all vehicle specifications. The committee analyzes data from various sources during the development process, creating technical specifications that reflect the immediate and forecasted needs of state transit agencies. These sources include historical data from previous contracts, information obtained at FDOT District Workshops, state and national industry conferences, maintenance consortium meetings, and in-depth research and testing of critical bus components conducted at FDOT's Springhill Bus Testing and Inspection facility. Specifications are written around performance standards when practical to avoid name branding and encourage competition.

The committee's overarching design goals include safety and crashworthiness, passenger comfort, environmental friendliness, ride quality, extended life, and cost-effectiveness. This is accomplished by a thorough evaluation of current manufacturing design features coupled with a detailed negotiated bid process. This is a full and lengthy analysis borne solely by the TRIPS program, affording state agencies the opportunity to procure quality vehicles that are safe, comfortable, and cost-effective.

\section{Other Program Elements}

The TRIPS program also provides a host of other support services such as defect issue resolution, technical assistance, training, data management, and manufacturing quality assurance activities. These elements are discussed in more detail in the next section of the report, which deals with program benefits and costs. 


\section{Chapter 3 \\ TRIPS Program Benefits and Costs}

At the outset of this study, CUTR researchers had intended to attempt to perform a life cycle cost analysis on TRIPS vehicles. Other costs and benefits were then to be identified and comparisons made with similar vehicles not procured through the TRIPS program. This approach was not able to be realized and comparable costs and metrics were developed in order to assess the benefits and costs. This chapter details the methods and the results of the approach.

\section{Vehicle Costs}

The average cost of vehicles procured through the TRIPS program was examined. There was a wide variety of vehicle types and configurations that were available through the TRIPS program over the study period from 2007 through 2011. Vehicles purchased through TRIPS are categorized by federal funding source: those that apply FTA Section 5310 funds, capital funding for meeting the transportation needs of elderly persons and persons with disabilities, and those not using Section 5310 Funds (non-5310). The non-5310 vehicle purchases are typically made by larger agencies for use as paratransit vehicles (a complimentary service for persons with disabilities unable to access an agency's fixed route system). Some larger vehicles made available through the TRIPS program are used in fixed route applications. Using the "Purchase Order" data within the TRIPS database, average vehicle costs by type are presented in Table 1.

Table 1 TRIPS Vehicle Purchase Orders, 2007-2011

\begin{tabular}{lcc}
\hline \multicolumn{1}{c}{ Vehicle Type } & $\begin{array}{c}\text { Number of Vehicles } \\
\mathbf{5 3 1 0}\end{array}$ & Average Cost \\
\hline Cutaway Bus & 254 & $\$ 76,795$ \\
Commuter Van & 28 & $\$ 36,083$ \\
Medium Duty Bus & 11 & $\$ 258,555$ \\
Minivan & 74 & $\$ 40,259$ \\
Standard Cutaway & 280 & $\$ 68,836$ \\
Small Cutaway Low Floor & 3 & $\$ 129,849$ \\
Subtotal & 650 & $\$ 70,271$ \\
\multicolumn{1}{c}{ Vehicle Type } & Number of Vehicles & Average Cost \\
Cutaway Bus & Non-5310 & \\
Commuter Van & 247 & $\$ 92,385$ \\
Medium Duty Bus & 18 & $\$ 304,963$ \\
Minivan & 18 & $\$ 38,012$ \\
Cutaway & 55 & $\$ 65,600$ \\
Standard Cutaway & 1 & $\$ 82,794$ \\
Subtotal & 309 & $\$ 88,092$ \\
Grand TOTAL & 573 & \\
\hline
\end{tabular}


These data were "scrubbed" for reporting anomalies, such as duplicate entries or missing entries. In all, there are 1,383 raw data entries in the version of the database that was used for this analysis, representing over $\$ 100$ million in transit vehicle purchases from 2007 through 2011.

In order to compare these average vehicle costs with national averages, a review of national data was conducted. Many of the vehicles purchased, particularly with FTA Section 5310 funds, are procured by small organizations, some with just a few vehicles. Due to the rigorous reporting requirements of the NTD by FTA, small agency information (small agency waiver for agencies with nine or fewer vehicles) is not reported nationally and is, therefore, unavailable for comparison purposes. For agencies that report at the national level, the cost of vehicle acquisition is not reported on an individual vehicle basis. In order to compare the average cost per vehicle purchased under the TRIPS program to other similar vehicles, researchers procured and accessed the 2011 APTA vehicle database.

The APTA report includes detailed vehicle data on more than 90,000 transit vehicles in operation in North America, with details on more than 13,000 demand response (DR) vehicles reported by 152 DR operating agencies. The APTA report categorizes DR vehicles as follows:

- Bus, double-deck (two levels, one above the other)

- Bus, suburban ( $>27.5^{\prime}$, one door, no luggage bays)

- Bus, transit ( $>27.5^{\prime}$, two doors)

- Small vehicle $\left(<27.5^{\prime}\right.$, minibus, van, car, SUV)

The APTA vehicle database was screened, and all sedans and vehicles with no cost or quantity data were removed. This left a dataset of more than 8,900 vehicles purchased in any year that remained in DR service at the agencies reporting. Table 2 below summarizes vehicles and their average costs by vehicle size.

Table 2 National Demand Response Vehicles - APTA 2011 2011 APTA Database Average Cost Demand Response - All Years

\begin{tabular}{ccc}
\hline Vehicle Type & Number & Average Cost \\
Small & 8,558 & $\$ 67,830$ \\
Bus $>27.5^{\prime}$ & 355 & $\$ 151,622$ \\
\hline
\end{tabular}

The APTA report also detailed the average cost by DR vehicle type for the purchases reported in 2010 and 2011. As stated above, the totals in Table 2 include costs of vehicles that were procured earlier than 2006, the earliest year reported in the current TRIPS database. All vehicles reported in APTA are wheelchair accessible and were placed into service from 1991 through 2011.

Table 3 below indicates the average costs for DR vehicles in the U.S. for 2010 and 2011 after adjustments were made, which included removing sedans and other vehicles without cost data. 
Table 3 APTA Vehicle Costs - 2010 and 2011 Acquisitions

2011 APTA Database Demand Response Average Cost - 2010 and 2011

\begin{tabular}{cc}
\hline Bus $>27.5^{\prime}$ & $\$ 196,650$ \\
Small & $\$ 67,203$ \\
\hline
\end{tabular}

For TRIPS vehicles from the Purchase Order database, vehicles meeting the "Small" APTA definition averaged $\$ 65,928$, and buses longer than $27.5^{\prime}$ averaged $\$ 214,487$ in 2010 and 2011. This portion of the database yielded a vehicle count of 321 small vehicles and 22 larger buses. These purchase order prices compare closely with the APTA figures and show a lower average cost for the majority of vehicles purchased in recent years. Table 4 compares the 2010 and 2011 average costs for "Small" DR vehicles.

Table 4 Small Vehicle Purchase Cost Comparison - FL vs. U.S., 2010 \& 2011

\begin{tabular}{ccccc}
\hline \multicolumn{2}{c}{ National Average } & \multicolumn{2}{c}{ TRIPS Program } & Difference \\
\hline $\begin{array}{c}\text { Number of } \\
\text { Vehicles }\end{array}$ & Average Cost & $\begin{array}{c}\text { Number of } \\
\text { Vehicles }\end{array}$ & Average Cost & \\
1338 & $\$ 67,203$ & 321 & $\$ 65,928$ & $\$(1,275)$ \\
\hline
\end{tabular}

On average, vehicles purchased through the TRIPS Program were $\$ 1,275$ less expensive than similar vehicles nationally for 2010 and 2011. This lower cost of acquisition for the majority of the vehicles purchased translates into $\$ 409,275$ in savings for the years 2010 and 2011 , or in excess of $\$ 204,000$ per year.

The larger buses available through the TRIPS program vary widely in cost, and the most expensive vehicles may or may not be used in traditional DR service. For the 2010-2011 period, the range of cost for the 22 vehicles longer than $27.5^{\prime}$ was $\$ 83,000$ to $\$ 300,000$.

\section{Vehicle Cost Trends}

The trend for vehicle costs over the study period was examined. For vehicles purchased using Section 5310 funding, the average cost per vehicle declined from 2007 to 2011. The majority of these purchase orders were for "Cutaway" or "Standard Cutaway" vehicles. For these vehicles, the cost ranged on average from a high of over $\$ 84,000$ to $\$ 63,369$ in 2011. Figure 1 displays the average cost for these vehicles during the study period of 2007 through 2011. 


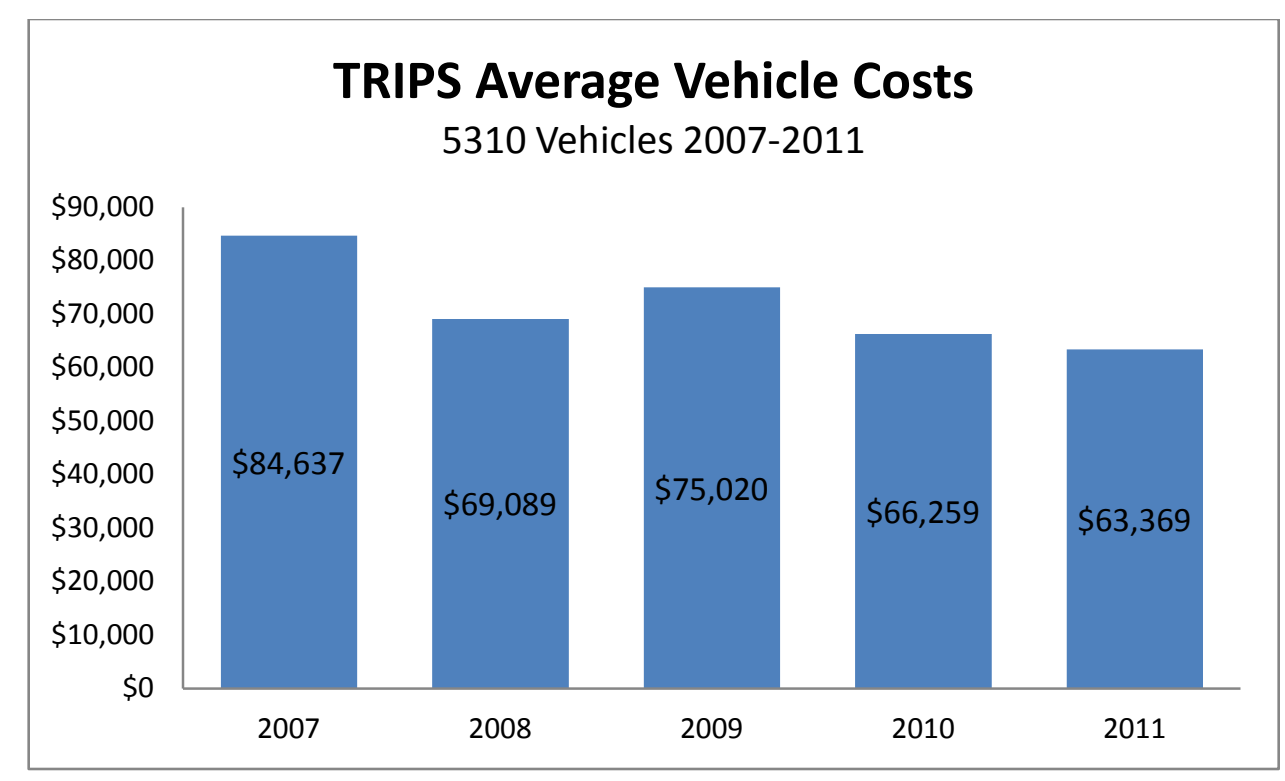

Figure 1 TRIPS Average Vehicle Costs - 5310 Vehicles

These cutaway vehicles have declined in acquisition cost from the $\$ 70,000$ to $\$ 80,000$ range in 2007 and 2008 to less than $\$ 64,000$ by 2011 . The purchase price for minivans, on the other hand, has remained fairly stable over the study period, rising modestly from $\$ 37,564$ in 2008 to $\$ 41,180$ in 2011 for 5310 funded vehicles.

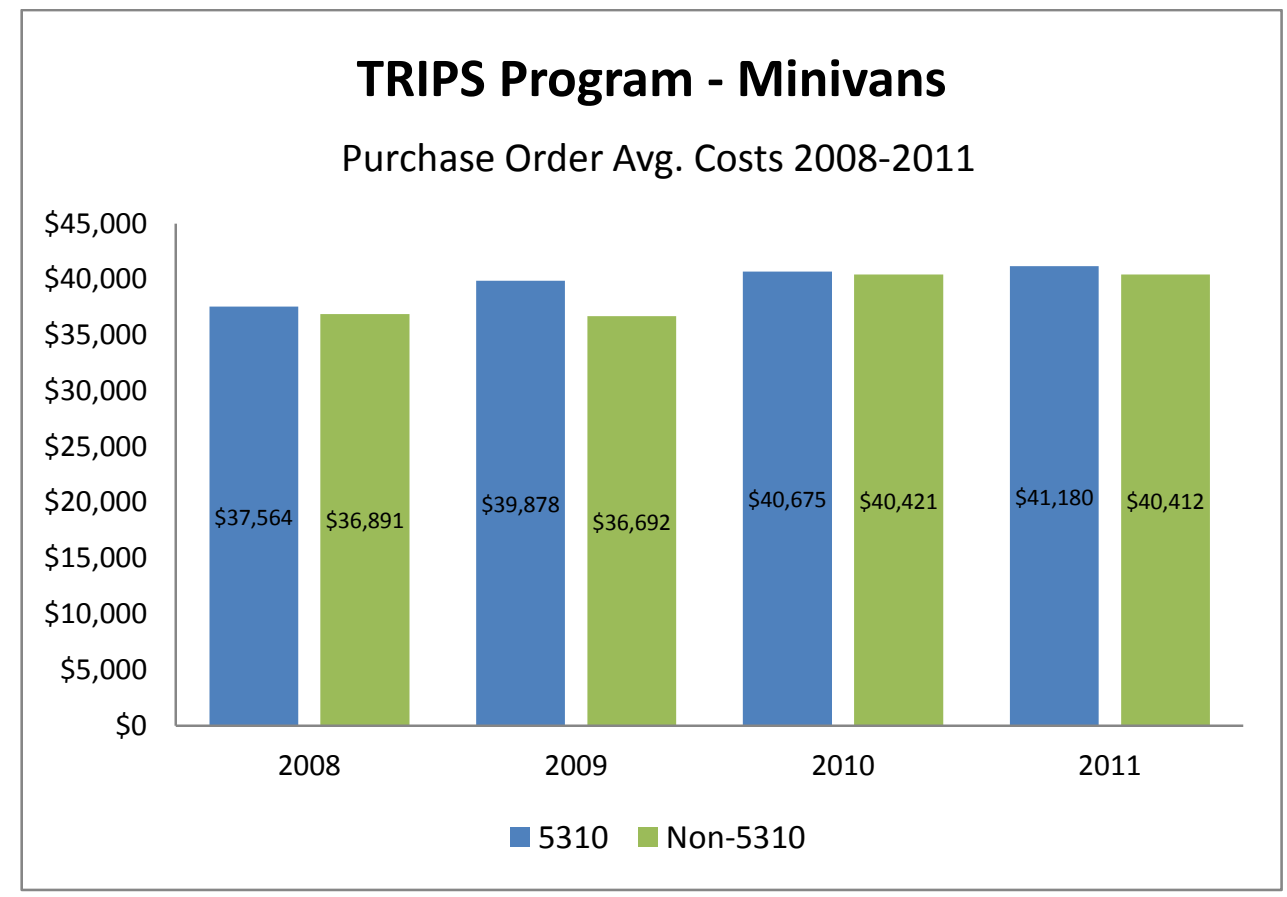

Figure 2 TRIPS Minivan Cost Trend 
Figures 3 and 4 display the average costs of the TRIPS vehicles procured over the study period with federal Section 5310 funds and non-5310 funds, respectively.

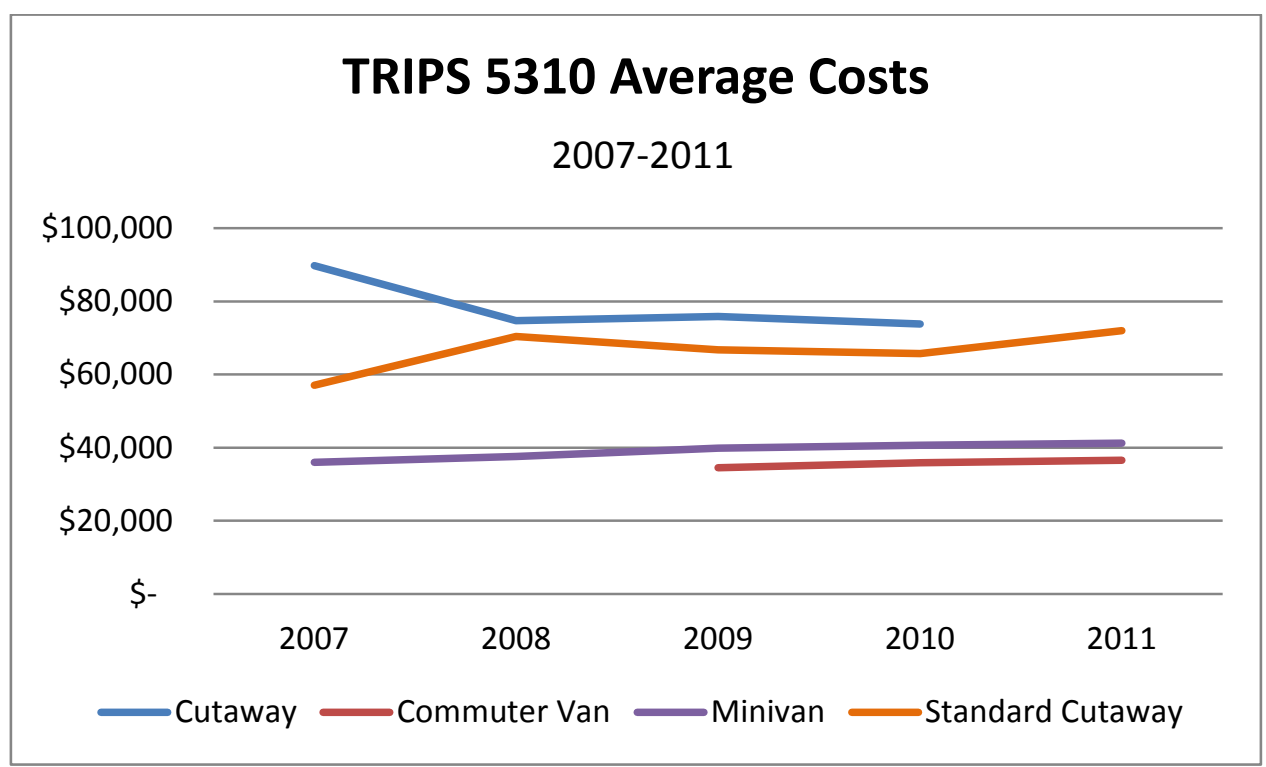

Figure 3 TRIPS 5310 Vehicle Average Acquisition Costs, 2007-2011

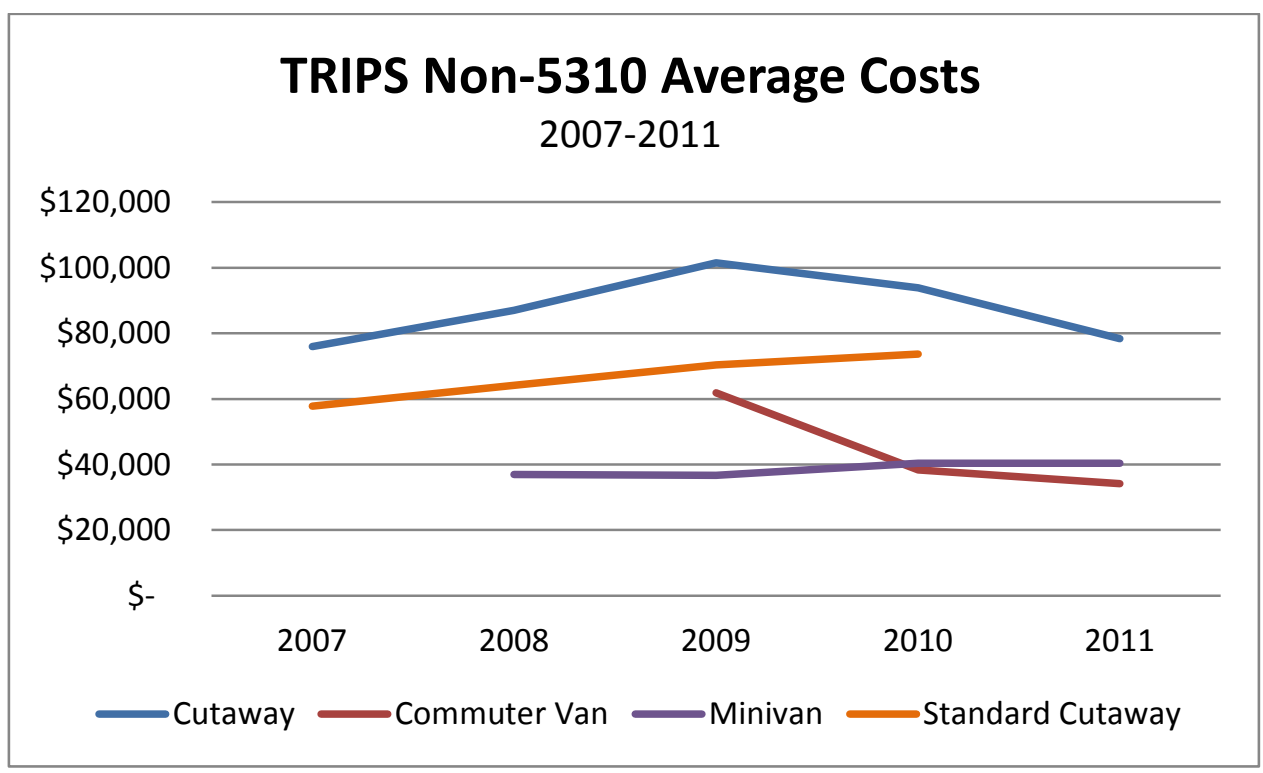

Figure 4 TRIPS Non-5310 Vehicle Average Acquisition Costs, 2007-2011 


\section{Vehicle and Passenger Safety}

Relying again on the NTD information for DR vehicles, a comparison was made between Florida's DR fleet and the national DR fleet. Data for years 2006 through 2011 for DR service were extracted and analyzed. Passenger miles reported nationally for the period were 4.9 billion, 490 million of which were in logged in Florida (10\% of the national total).

Fatalities were excluded from any comparative review because the frequencies were extremely low. In fact, for several years no DR fatalities were reported at either the state or national levels. In an attempt to quantify any benefit that may be derived from the stricter vehicle specification and vehicle crash testing that are a part of the TRIPS program in Florida, researchers examined passenger injuries and costs per collision. Figure 5 displays the data and the trend for Florida and the U.S.

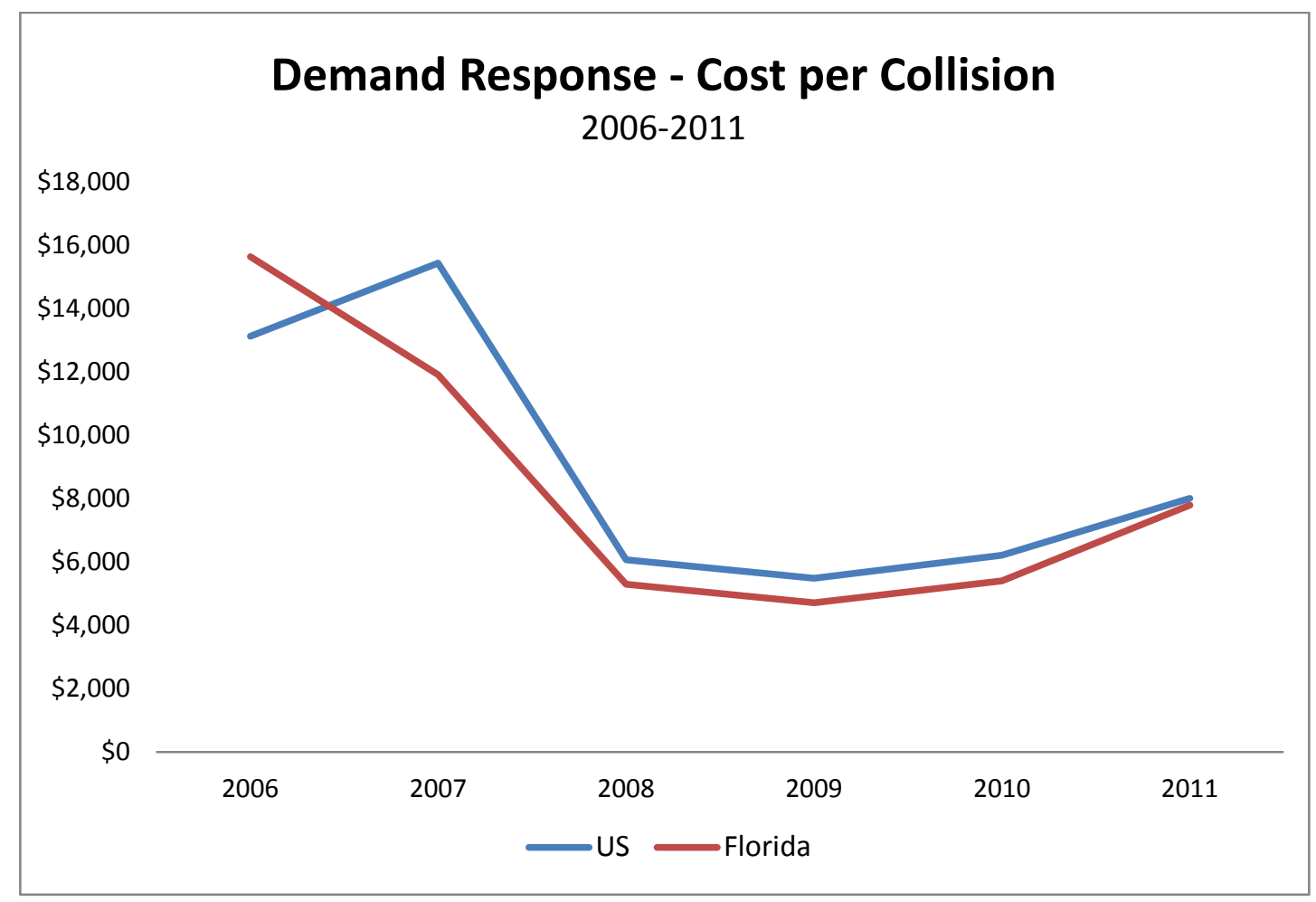

Figure 5 Vehicle Repair Cost per Collision - Florida vs. U.S.

Since 2007, the average cost to repair collision damage for a DR vehicle in Florida has been lower than the national average. Over the 2006 through 2011 period, Florida's collision costs were approximately $\$ 600$ lower for each incident. This may not be solely due to increased vehicle integrity; nonetheless, the data support lower costs of repair.

Over the study period there was an average of 39 collisions per year involving Florida DR vehicles reported to NTD. Based on the lower cost to repair the vehicle damage, this 
translates into an estimated annual cost avoided of $\$ 23,262.52$. Given that the DR data reported in the NTD is a subset (about 1,800 vehicles) of all TRIPS vehicles in service in Florida, this figure is likely low.

Injury data for DR service was also examined. Given that the focus of this study is on the vehicles, passenger injuries seemed the most relevant component of the injury data. Passenger miles and total passenger injuries were used to calculate a passenger injury rate expressed in passenger injuries per one million passenger miles of travel (PMT).

For each year except 2010, passenger injury rates were lower for Florida's DR service than the national rates, based on NTD data. In fact, for the six-year period, the injury rate was on average 16.53 percent lower for passengers in Florida than for the U.S. Figure 6 illustrates the calculated rates expressed in terms of injuries per one million PMT.

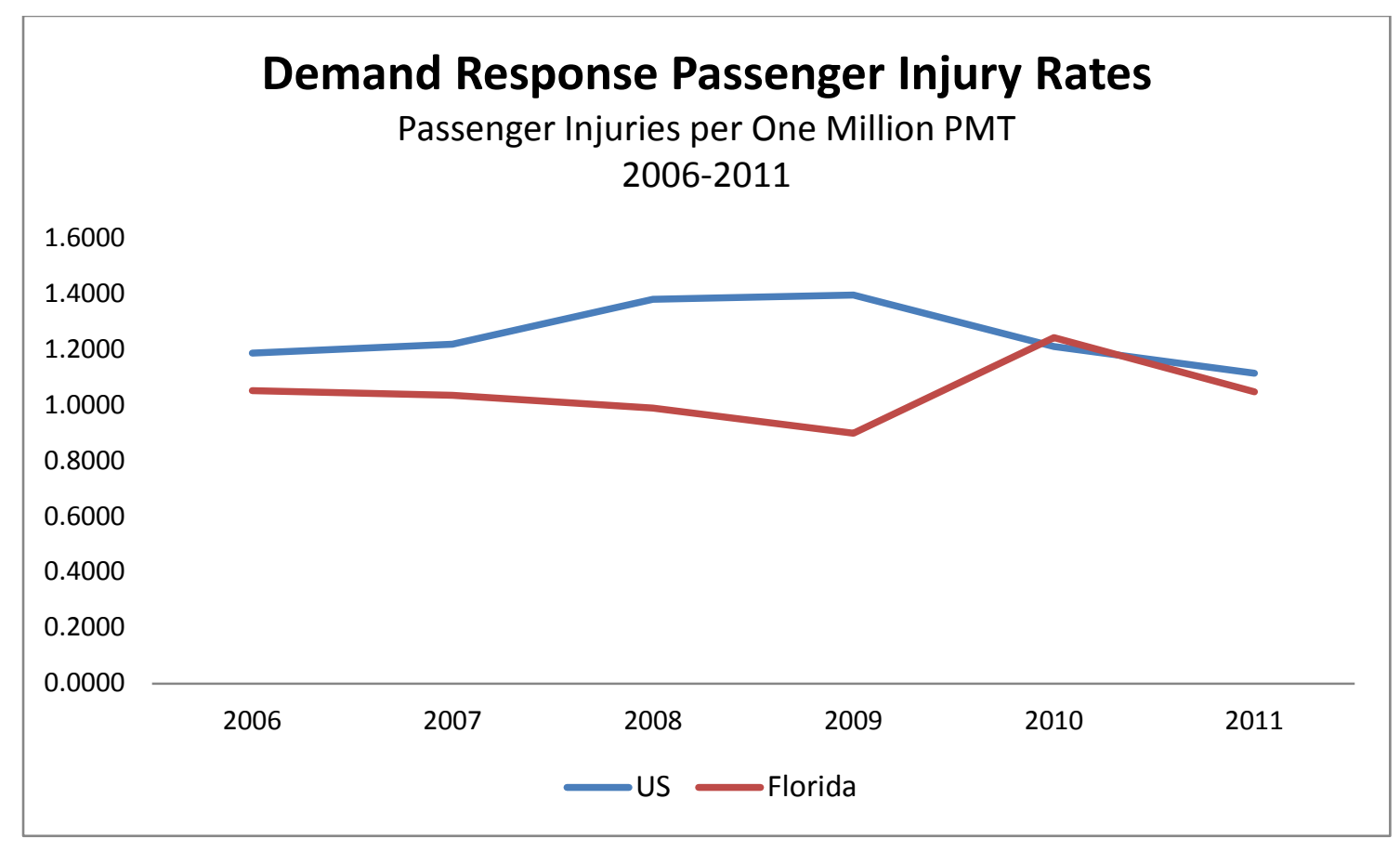

Figure 6 Passenger Injury Rates - Florida vs. U.S.

The NHTSA report on the economic impact of motor vehicle crashes from 2002 assigns estimated costs to highway injuries. ${ }^{2}$ In this analysis, non-fatal injuries are monetized at $\$ 50,523$ per incident, adjusted current day dollars. In 2011, NTD reported 76.3 million DR passenger miles traveled in Florida.

2 L.J. Blincoe, et al., "The Economic Impact of Motor Vehicle Crashes 2000," U.S. Department of Transportation, National Highway Traffic Safety Administration, (Washington, D.C: 2002). 
Applying the difference in the six-year average injury rates for Florida and the U.S. to the Florida PMT provides an estimated societal savings in Florida based on the miles passengers traveled on the state's DR system. The rate differences are presented below in Table 5 .

\begin{tabular}{lcc}
$\begin{array}{c}\text { Table 5 DR Passenger Injury Rates per One Million } \\
\text { PMT - FL vs. U.S., 2006-2011 }\end{array}$ \\
\hline \multicolumn{1}{c}{ Year } & U.S. & Florida \\
\hline 2006 & 1.1868 & 1.0522 \\
2007 & 1.2189 & 1.0350 \\
2008 & 1.3805 & 0.9898 \\
2009 & 1.3952 & 0.8983 \\
2010 & 1.2102 & 1.2419 \\
2011 & 1.1141 & 1.0481 \\
$2006-2011$ Average & 1.2510 & 1.0442 \\
\hline Six-Year Difference & & -0.2067 \\
Percent Difference & & $-16.53 \%$ \\
\hline
\end{tabular}

In simple terms, if the passenger injury rate for Florida's DR users was the same as the national average, there would be 16 additional injuries annually. When the NHTSA figure for the cost per injury is applied, an annual cost avoidance of $\$ 797,237$ is calculated. This cost avoidance is only for the portion of trips made on vehicles reported to FTA in the NTD. This figure would be significantly higher if applied to all TRIPS passenger miles of travel.

\section{Vehicle Warranty Tracking and Administration}

A mentioned in Chapter 2 of the report, the TRIPS program provides oversight and management of the remediation of vehicle deficiencies prior to delivery and during the warranty period. Vehicle issues are identified during the pre-delivery inspection procedure performed at the Spring Hill Facility. Inspection details are entered into the TRIPS database. The database contains information on pre- and post-delivery inspections, and information on any encountered issues is recorded in the TRIPS "Situation" table, which allows recording issues related to 14 major situation categories.

These data were examined to document the scale of the effort that is involved with solving vehicle problems. The data are assumed to be accurate for the 2008 through 2011 period. A copy of the Situation table is shown in Table 6 . This table indicates that more than 4,600 issues were recorded as requiring attention over the four-year period for vehicles procured through TRIPS. Once the situation is addressed, results are recorded in the "Action Taken" table, as summarized in Table 7. The number of actions taken is less than the number of situations because under one action, one or more mechanical issues can be addressed. 
Table 6 TRIPS Situation Table

\begin{tabular}{|l|c|}
\hline \multicolumn{1}{c}{ SITUATION CATEGORY } & COUNT \\
\hline ADA (Lift Restraint System) & 319 \\
\hline Body (Interior/Exterior) & 385 \\
\hline Brakes & 1 \\
\hline Chassis & 36 \\
\hline Drivetrain & 27 \\
\hline Electrical & 871 \\
\hline Emissions & 21 \\
\hline Engine & 37 \\
\hline Interior & 1 \\
\hline Seating & 27 \\
\hline Suspension & 9 \\
\hline Transmission & 5 \\
\hline Wheels & 11 \\
\hline Other & 2,124 \\
\hline Not Reported & 775 \\
\hline Total & 4,649 \\
\hline
\end{tabular}

More than 1,800 specific actions were recorded in response to the issues that were raised with the associated reported "Situations."

Table 7 TRIPS Action Taken Table

\begin{tabular}{|l|c|c|}
\hline \multicolumn{1}{c}{ ACTION CATEGORY } & COUNT & AVERAGE MILES \\
\hline Air-Conditioning & 139 & 1,166 \\
\hline Electrical Control Panel & 64 & 1,167 \\
\hline Engine Compartment & 88 & 1,217 \\
\hline Event Data Recorder & 91 & 1,386 \\
\hline Exterior Fit & 164 & 1,296 \\
\hline Interior & 203 & 1,059 \\
\hline Items Shipped Loose & 92 & 1,145 \\
\hline Other & 296 & 1,052 \\
\hline Power Management & 8 & 1,255 \\
\hline Seats & 35 & 1,029 \\
\hline Undercarriage & 459 & 1,201 \\
\hline Water & 34 & 1,096 \\
\hline Wheelchair Lift & 165 & 1,187 \\
\hline Total & 1,838 & \\
\hline
\end{tabular}

While it was not possible to calculate the potential cost savings or estimate the cost avoidance related to having these repairs performed by the manufacturer or dealer predelivery or under warranty, there is no question that this service adds value to the participating agencies. The TRIPS program negotiates for extended warranties on both the primary vehicle and the larger subcomponents. Program technicians facilitate warranty 
claims on behalf of the agencies, in some cases directly with the warranty providers. This is clearly a benefit to the agencies procuring vehicles under the program.

\section{Procurement Management}

Personnel engaged by FDOT under the TRIPS program contract with CUTR to manage, formulate, and recommend policies and procedures to effectively administer a vehicle procurement process. There are savings to individual agencies associated with not having to become familiar with and interpret purchasing administrative regulations and policies, or preparing specifications, legal advertisements, formal bid invitations, and procurement matters. TRIPS staff also monitor, audit, and report on program results to include collecting and analyzing data as appropriate. The results of these analyses benefit all agencies in the state.

Most Florida agencies are small in size and procure only a single vehicle. Small agencies often lack the requisite administrative resources to conduct a formal procurement for FTA Section 5310 vehicles. TRIPS relieves agencies of the administrative burdens required in the development of technical specifications and competitive procurement practices, and provides them with the opportunity to take advantage of TRIPS contracts that incorporate sound technical and safety specifications, enhanced vehicle inspection practices, mandated dealer coordination, training, technical assistance, and extended warranties.

\section{Technical Assistance}

Technical assistance to the operating agencies is also provided through the TRIPS program mainly to provide agencies with expertise relating to defect identification and resolution. The program technicians maintain an electronic record-keeping platform that details events and concerns initiated by the agencies. Industry issues are also handled in this manner. This support also includes Listserv information and knowledge sharing, specific case-by-case issue resolution, manufacturer fleet alerts, NHTSA defect investigations, thermal event forensic analysis, and subcomponent product improvement campaigns. Some of these items are vehicle or agency specific and are resolved accordingly. Others are statewide, and resolution timelines, actions taken, and final reports are created and issued that initiate corporate campaigns to deal with the problems. This support helps ensure public safety and program integrity.

For the years 2010-2011, the program averaged 63 issues resolved annually. These issues reflect initiating contact with one or more agencies, vendors, manufacturers, or dealers to effectively resolve the outstanding issue.

\section{Vehicle Condition and Useful Life}

Researchers examined biennial vehicle inspection reports and inventories compiled by several of Florida's district offices to understand the scope and breadth of the TRIPS program in serving customer needs within regions throughout the state. Since vehicle age data are not collected in a single repository, the inspection reports were examined in an attempt to find information on TRIPS vehicles useful life. The biennial inspection of vehicles is required as a condition of federal grants (49 CFR 18.32). In addition, consistent with FDOT's "Transit Vehicle Inventory Management" procedure, this biennial inventory 
inspection includes all vehicles purchased with FTA Section 5310 (Elderly and Persons with Disabilities), Section 5311 (Nonurbanized Area Formula), Section 5316 (Job Access and Reverse Commute), and Section 5317 (New Freedom) programs, and public transit vehicles (excluding public transit fleet lease vehicles) in which the FDOT participated at a level of 50 percent or more in the purchase price.

District inspection reports were available for Districts One, Two, Three, Six, and Seven.

\section{District One}

District One vehicles were inspected in November and December of 2011. At the time of the inspection, 44 different agencies maintained and operated a total of 280 vehicles that included buses, vans, sedans, and a club wagon. Vehicles entered service between 1993 and 2012, and 34 percent of the vehicles (96 vehicles) had been in service for more than five years. Twenty-nine new vehicles were issued in 2012 and represent 10 percent of the vehicle inventory. Buses constitute the majority $(66.1 \%)$ of vehicles. Combined mileage of the vehicles (263 with documented mileage) equaled 12.9 million miles, with an average vehicle mileage of nearly 55,000. Of the 263 vehicles with documented mileage, almost 11 percent ( 28 vehicles) had logged mileage in excess of 150,000 miles. A 2006 bus logged 315,792 miles, the highest mileage reported in District One.

The maximum number of vehicles maintained by a single agency was 48 , while the average number was 6 , and the most frequent number of vehicles maintained by an agency was one.

\section{District Two}

At the time of this report, 38 different agencies maintained and operated a total of 199 vehicles that included buses, vans, cutaways, a sedan, a station wagon, and a truck. Vehicles entered service between 1990 and 2012, and 26 percent of the vehicles (51 vehicles) had been in service more than five years. Twelve new vehicles were issued in 2012 and represent 6 percent of the vehicle inventory. Buses make up the majority (67.8\%) of vehicles. The maximum number of vehicles maintained by a single agency was 18 , while the average number was 5 , and the most frequent number of vehicles maintained by an agency was one.

\section{District Three}

As of this writing, 18 different agencies maintained and operated a total of 120 vehicles that included buses, vans, station wagons, and a cutaway. Vehicles entered service between 1998 and 2012, and 10 percent of the vehicles (12 vehicles) have been in service in excess of five years. Nine new vehicles (7.5\%) entered service in 2012. Buses represented the majority $(52.5 \%)$ of vehicles. The maximum number of vehicles maintained by a single agency was 29, while the average number was 7 , and the most frequent number of vehicles maintained by an agency was one. 


\section{District Six}

District Six vehicles were inspected during April through June 2010. At the time of the inspection, 62 different agencies maintained and operated a total of 229 vehicles that included buses, vans, station wagons, pickups, ultra-low-floor trolleys, and a sedan. Vehicles entered service between 1990 and 2010, and 62 percent of the vehicles (141 vehicles) exceeded five years of age. Buses represented the majority (54.1\%) of vehicles. Combined mileage of the vehicles ( 225 with documented mileage) equaled 14 million miles, with an average vehicle mileage of 62,000 . Of the 225 vehicles with documented mileage, 6.2 percent (14 vehicles) had logged mileage in excess of 150,000 miles. A 2002 bus logged 247,823 miles, the highest mileage reported in District Six.

The maximum number of vehicles maintained by a single agency was 17 , while the average was 4 , and the most frequent number of vehicles maintained by an agency was one. The inventory report included 188 vehicles from private nonprofit agencies and 41 vehicles from public agencies. The inventory report also contained information regarding maintenance plans, maintenance records, and determined whether vehicles were properly maintained.

Based on the findings of the 2010 Vehicle Inventory for FDOT District Six, most agencies performed required maintenance delineated by a maintenance plan. The findings are reassuring in terms of the maintenance of the vehicles by private and public agencies given that the vehicles show extensive use well beyond their projected useful life. Information regarding vehicle damage and vehicles out of service was also included in the inventory report. This information regarding the care and handling of the vehicles by private and public agencies is critical in evaluating agency performance.

\section{District Seven}

At the time of this report, 54 different agencies maintained and operated a total of 482 vehicles that included buses, vans, sedans, station wagons, and a cutaway. Vehicles entered service between 1985 and 2012, and 46.5 percent of the vehicles (224 vehicles) exceeded five years of age. Thirty-six new vehicles (7.5\%) were issued in 2012 . Vans represented the majority $(54.1 \%)$ of vehicles. The maximum number of vehicles maintained by a single agency was 35 , while the average was 9 , and the most frequent number of vehicles maintained by an agency was one.

District-related information is summarized in Table 8. 
Table 8 District Agency and Vehicle Information

\begin{tabular}{|c|c|c|c|c|c|}
\hline District & $\begin{array}{c}\text { Number of } \\
\text { Agencies }\end{array}$ & $\begin{array}{c}\text { Vehicle } \\
\text { Count }\end{array}$ & $\begin{array}{c}\text { New } 2012 \\
\text { Vehicles }\end{array}$ & $\begin{array}{c}\text { Vehicles in } \\
\text { Service >5 } \\
\text { Years }\end{array}$ & $\begin{array}{c}\text { Vehicles with } \\
>150,000 \\
\text { Miles }\end{array}$ \\
\hline One & 44 & 280 & 29 & 96 & 28 \\
\hline Two & 38 & 199 & 12 & 51 & -- \\
\hline Three & 18 & 120 & 9 & 12 & -- \\
\hline Six* & 62 & 229 & -- & 62 & 14 \\
\hline Seven & 45 & 482 & 36 & 224 & -- \\
\hline Total & 210 & 1,310 & 86 & 445 & 42 \\
\hline
\end{tabular}

*District Six inspection conducted in 2010.

Agencies in District Six operate 229 vehicles: 14 vehicles have logged more than 150,000 miles, 141 vehicles have been in service for more than five years, and 186 vehicles were found to be in good condition.

The review of the five district inspection reports reveals that 34 percent of the TRIPS fleet has been in service for more than five years and 3.3 percent of the vehicles had recorded mileage of over 150,000 miles. Based on the review of these reports, the findings support that in terms of performance data, the vehicles show extensive use well beyond their projected useful life. The specified useful life of TRIPS vehicles is compared to the requirements of other states' vehicles in a subsequent section of this report (Chapter 4 ). A comparison with other states' useful life requirement shows that Florida's TRIPS vehicles are required to achieve a longer useful life than others.

Consistent and accessible data on life-to-date miles and maintenance costs were not readily available. While collection of these data on a real-time basis may be impractical given the nature of many of the vehicle grant recipients, future calculations of the TRIPS program efficacy would be eased with such a reporting mechanism. Suggestions on this issue are provided in the Findings and Conclusions section, Chapter 5.

\section{TRIPS Program Costs}

The Department invests annually in funding the TRIPS program through CUTR at the University of South Florida. This funding covers the manpower and facility burden associated with specification development, assembly inspection, post-delivery inspection and acceptance, program administration and price negotiations, technical support, and training.

The contractual awards for the study period were collected and translated into yearly costs. Table 9 below illustrates the data. 
Table 9 FDOT TRIPS Funding - CUTR Grants 2005-2013

\begin{tabular}{cccc}
\hline Project Start & Project End & Budget & Annual Cost \\
\hline $11 / 1 / 2005$ & $10 / 31 / 2008$ & $\$ 1,440,000$ & $\$ 480,000$ \\
$10 / 1 / 2008$ & $11 / 30 / 2011$ & $\$ 1,620,000$ & $\$ 540,000$ \\
$* 7 / 9 / 2009$ & $7 / 8 / 2011$ & $\$ 350,000$ & $\$ 350,000$ \\
$12 / 1 / 2011$ & $11 / 30 / 2012$ & $\$ 540,000$ & $\$ 540,000$ \\
$12 / 1 / 2012$ & $11 / 30 / 2013$ & $\$ 540,000$ & $\$ 540,000$ \\
\hline *An additional $\$ 175 k$ per year for two years was added due to increased TRIPS activity \\
associated with additional federal stimulus funding to the state.
\end{tabular}

Because the range of years included in this study is from 2007 through 2011, the multiyear contract that started in November 2005 needed to be included in this analysis. On an annual basis, the program costs have been stable at $\$ 540,000$ per year with the exception of an additional \$175,000 in grants for the TRIPS program in FY 2009-2010 and FY 2010-2011.

Additional funding was provided to handle the programmatic increases that were anticipated from the additional capital funding coming to Florida as a result of ARRA. An increase in federal funding for the Section 5311 nonurbanized transit capital program was targeted at additional investments in transit rolling stock. Some of the start and end dates indicate overlap and gap due to grant processing times and other administrative issues. Figure 7 charts the annual costs FDOT has incurred for CUTR's managing and running the program.

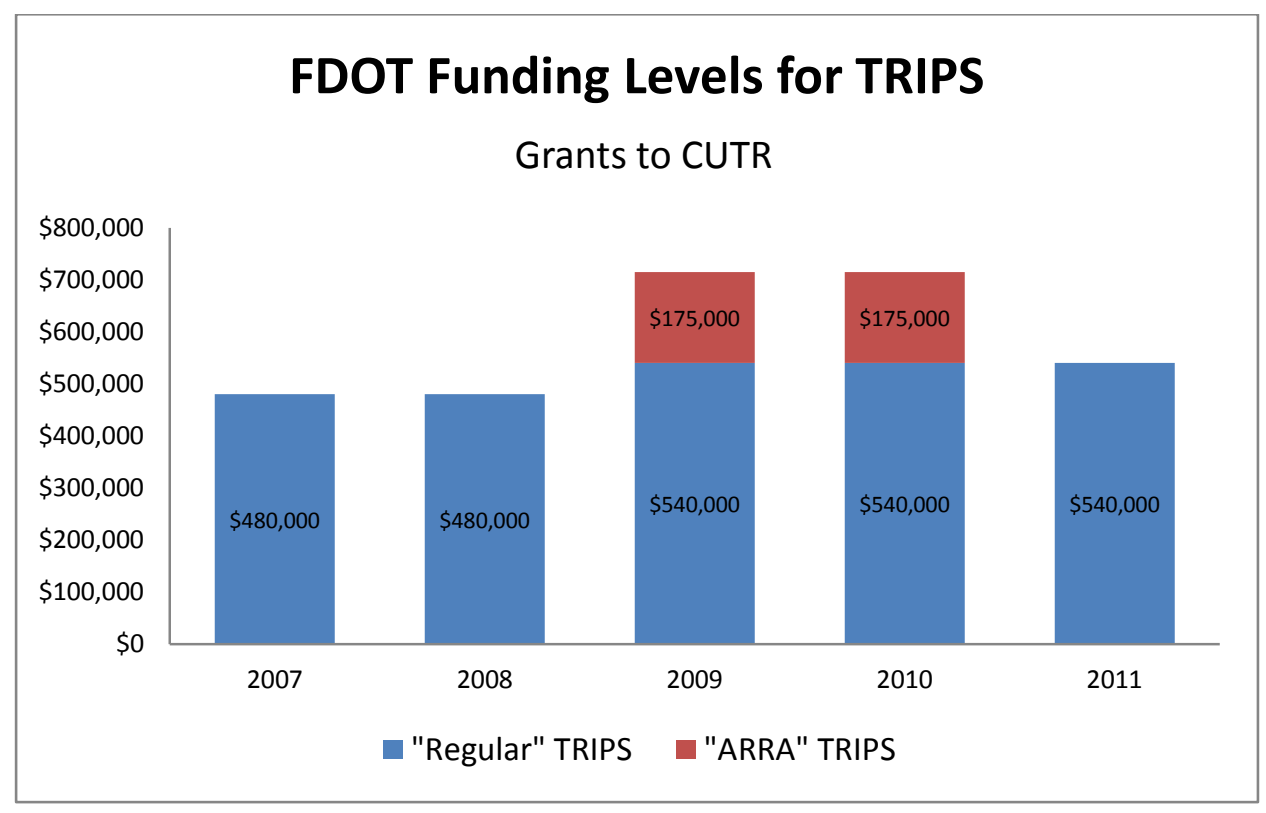

Figure 7 Annual FDOT Funding of TRIPS - CUTR 2007-2011

Relying on the PO portion of the TRIPS Vehicle Database, researchers were able to calculate the TRIPS program costs on a unit basis. By dividing the total costs for the years 2007 through 2011 by the 1,223 vehicles reported in the database, a cost of $\$ 2,395.75$ was 
calculated for each vehicle ordered in the time frame examined. This represents 3.25 percent of the average vehicle cost for all vehicles reported in the PO database for the 2007 through 2011 period.

\section{TRIPS Program Benefits and Cost Findings}

The TRIPS program handled over $\$ 100$ million in transit vehicle purchases from 2007 through 2011. On average, vehicles purchased through the TRIPS program were \$1,275 less expensive than similar vehicles nationally for 2010 and 2011 . This lower cost of acquisition for the majority of the vehicles purchased translates into $\$ 409,275$ savings for the years 2010 and 2011, or in excess of $\$ 204,000$ per year.

The average cost per vehicle funded with Section 5310 funds under TRIPS has declined from 2007 to 2011 . The acquisition cost had declined from the $\$ 70,000$ to $\$ 80,000$ range in 2007 and 2008 to less than $\$ 64,000$ by 2011 .

Since 2007, the average cost to repair collision damage for a DR vehicle in Florida has been lower than the national average. During the 2006 through 2011 period, Florida's collision costs were approximately $\$ 600$ lower for each incident. Annualized, this translates into an estimated annual cost avoided of $\$ 23,262.52$.

Passenger injury rates were lower for Florida's DR service (a subset of the TRIPS vehicles) than the national rates based on NTD data. This 16.53 percent lower rate translates into an annual cost avoidance of $\$ 797,237$ when applying NHTSA costs per injury.

There is clear evidence of aggressive pre-delivery and warranty tracking and issue resolution. More than 4,600 issues were documented requiring attention and resolved for TRIPS vehicles from 2008 through 2011. TRIPS relieves small and large agencies of the administrative burdens required in the development of technical specifications and competitive procurement practices, and provides them with the opportunity to take advantage of TRIPS contracts that incorporate sound technical and safety specifications, enhanced vehicle inspection practices, mandated dealer coordination, training, technical assistance, and extended warranties.

The review of the five FDOT district inspection reports revealed that 34 percent of the TRIPS fleet has been in service for more than five years and 3.3 percent of the vehicles had recorded mileage of over 150,000 miles. Based on the review of these reports, the findings support that in terms of performance data, the vehicles show extensive service well beyond their projected useful life. A comparison with other states' useful life requirement for vehicles purchased with Section 5310 funds shows that Florida's TRIPS vehicles are required to achieve a longer useful life.

On an annual basis, the program costs for CUTR to manage and operate the TRIPS program have been stable at $\$ 540,000$ per year, with the exception of an additional $\$ 175,000$ in grants in FY 2009-2010 and FY 2010-2011 because of the increased activity resulting from ARRA funding. When converted to a cost per unit, $\$ 2,395.75$ was calculated as the cost 
attributed to CUTR program operations for each vehicle ordered in the time frame examined.

During the period from 2007 through 2011, FDOT engaged the services of CUTR to manage and staff the TRIPS program. On average, the annual cost over this period to FDOT was $\$ 586,000$. Table 10 summarizes the cost avoidance or savings figures assembled thus far and adds the program costs to achieve a net cost or savings calculation based on all the data and assumptions presented.

Table 10 Net Annualized Costs and Savings - TRIPS Program

\begin{tabular}{ll}
\hline Cost Category & $\begin{array}{l}\text { Annualized Cost or (Savings) } \\
\text { to Florida }\end{array}$ \\
\hline Vehicle Acquisitions & $(\$ 204,000)$ \\
Accident Repairs & $(\$ 23,263)$ \\
Injuries & $(\$ 767,273)$ \\
CUTR Program Management & $\$ 586,000$ \\
Net Annualized Costs or (Savings) & $(\$ 408,536)$ \\
\hline
\end{tabular}

The net savings, or more accurately stated, the costs avoided, total over $\$ 400,000$ per annum for the TRIPS fleet versus the U.S. DR fleet based on the data used, the analysis presented, and the assumptions included in this chapter of the report. 


\section{Chapter 4 Section 5310 Practices throughout the U.S.}

The research team conducted an evaluation of current practices in other states, with the objective of collecting additional quantitative and anecdotal evidence that could provide insight into Florida's TRIPS program in relation to programs in other states.

FTA provides a variety of financial assistance programs to states to develop, improve, maintain, and operate existing public transportation systems. Approximately 638 (53.3\%) of the 1,197 vehicles Florida agencies have procured through TRIPS since 2008 were purchased with Section 5310 program funds to improve mobility for elderly individuals and individuals with disabilities. The remaining 559 (46.7\%) vehicles were procured with nonSection 5310 program funds.

The Section 5310 program was established as a discretionary capital assistance program in 1975. ${ }^{3}$ Through the program, grants were awarded to private nonprofit organizations to serve the transportation needs of the elderly and persons with disabilities in areas where public transit was inadequate or inappropriate. Apportionment among the states by formula for distribution to local agencies was made a statutory requirement by the Surface Transportation Efficiency Act of 1991 (ISTEA), which introduced eligibility to public agencies under limited circumstances to facilitate and encourage the coordination of human service transportation. ISTEA allowed acquisition of service in lieu of purchasing vehicles as an eligible expense to promote the use of private sector providers and coordination with other agencies. ISTEA also introduced the ability to transfer flexible funds to the program from certain highway programs, and the flexibility to transfer funds from the Section 5310 program to rural and urban formula programs. FTA increasingly required coordination of the program with other federal human service transportation programs. The Transportation Equity Act for the $21^{\text {st }}$ Century (TEA-21) reauthorized the Section 5310 program in 1998. Funding levels for the program were increased in the absence of any significant program changes. SAFETEA-LU, enacted by Congress in 2005, required that Section 5310-funded projects be derived from a locally developed, coordinated public transit-human services transportation plan. It also introduced a seven-state pilot program that enabled the identified states to use up to one-third of the funds apportioned to them for operating assistance, and allowed transfers to Section 5307 or 5311, but only to fund projects selected for Section 5310 program purposes.

Under Department of Transportation regulations, "Uniform Administrative Requirements for Grants and Cooperative Agreements to State and Local Governments," 49 CFR Part 18 (sometimes referred to as the Common Grant Rule), the state may rely on its own laws and procedures instead of federal procedures in the areas of financial management systems, equipment, and procurement. A state may pass its procedures down to its subrecipients

\footnotetext{
${ }^{3}$ Federal Transit Administration, "Elderly Individuals and Individuals with Disabilities Program
} Guidance and Application Instructions" (Circular 9070.1F, May 1, 2007). 
that are public authorities, and the state's procedures apply to a third-party contract when a private provider of public transportation services enters into a third-party contract with a state or public subrecipient of a state. Private nonprofit subrecipients must comply with the "Uniform Administrative Requirements for Grants and Agreements with Institutions of Higher Education, Hospitals, and Other Nonprofit Organizations," 49 CFR Part 19.

Title 49 U.S.C. 5310(a)(1) authorizes funding for public transportation capital projects planned, designed, and carried out to meet the special needs of elderly individuals and individuals with disabilities. Title 49 U.S.C. 5310(a)(2) provides that a state may allocate the fund apportioned to it to:

- a private nonprofit organization, if public transportation service provided by state and local government authorities under Section $5310(a)(1)$ is unavailable, insufficient, or inappropriate; or

- a governmental authority that is approved by the state to coordinate services for elderly individuals and individuals with disabilities, or certifies that there are not any nonprofit organizations readily available in the area to provide the special service.

Section 5310 program measures are governed by the Government Performance Results Act (GPRA), which by law requires FTA to "establish performance goals to define the level of performance" and also to "establish performance indicators to be used in measuring relevant outputs, service levels, and outcomes" for each of its programs. FTA designed the following measures to fulfill its obligations under GPRA. The measures are at a program level rather than to assess individual grants.

- FTA captures overall program measures to be used with GPRA and the Performance Assessment Rating Tool process for the U.S. Office of Management and Budget.

- FTA conducts independent evaluations of the program focused on specific data elements to better understand implementation strategies and related outcomes associated with the program.

- FTA collects quantitative and qualitative program information on the following two measures established for the Section 5310 program as part of the annual report that each grantee submits to FTA:

1. Gaps in Service Filled: transportation options provided that would not otherwise have been available for older adults and individuals with disabilities, measured in numbers of older adults and individuals with disabilities afforded mobility they would not have without program support.

2. Ridership: actual or estimated number of rides (as measured by one-way trips) provided annually for individuals with disabilities and older adults on Section 5310-supported vehicles and services.

As a condition for receipt of Section 5310 funds, FTA requires each state to produce and maintain a State Management Plan (SMP) that describes the state's policies and procedures for administering the state-managed portion of the program. All states are required to have an approved SMP on file in the FTA regional office. Additions or amendments to the SMP 
must be made and submitted to FTA whenever a state significantly changes its management of the program, or when new program management requirements are imposed by FTA.

Changes may also be required due to a state management review by FTA. While there is no prescribed format for the SMP, FTA provides recommendations regarding the nature of the content required. At a minimum, the document must include the state's objectives, policies, procedures, and administrative requirements, in a form readily accessible to potential subrecipients, state staff, FTA, and the public. The SMP should also include documentation required to comply with FTA annual certifications and assurances that delineate basic requirements for Section 5310. The SMP's primary purposes are to serve as the basis for FTA state-level management reviews of the program and to provide public information on the state's administration of the Section 5310 program. The SMP may also be used internally by the state as a program guide for local project applicants. If the state has other relevant documentation that provides the same information requested for the SMP, such as an annual applications manual, it may be included by reference as an attachment.

To gain an understanding of how each state administers its Section 5310 program, researchers assembled SMPs and annual application manuals for all states and the District of Columbia (See Appendix A). Table 11 delineates the type of document that was available from each state (i.e., a state management plan or an annual application manual).

The majority of states posted an SMP rather than an annual application manual online. SMPs generally provided more detail regarding program information and administration; often contained material for all grant programs available within the state; referenced direct links to FTA guidelines, circulars, and certifications and assurances; and, were slightly less current than annual application manuals, although these manuals appeared to fulfill FTA information requirements. Florida's SMP comprises a series of topic procedures (the FDOT Topic Procedure for 5310 is Topic Number 725-030-010-j, amended on June 8, 2010), in addition to an annual application package, which was current at the time of the review. The review focused on the following practices, which are discussed in detail in this section of the report.

- Section 5310 Designated Administrator

- Program administration

- Federal/local match

- State administrative expenses

- Vehicle useful life and replacement standards

- Procurement and specifications

- Pre-award and post-delivery reviews

- Maintenance plan and preventive maintenance

- Compliance review schedule

- Reporting requirements 
Table 11 State Management Plan vs. Application Manual

\begin{tabular}{|c|c|c|c|c|c|}
\hline State & $\begin{array}{c}\text { State } \\
\text { Management } \\
\text { Plan }\end{array}$ & $\begin{array}{c}\text { Annual } \\
\text { Application } \\
\text { Package }\end{array}$ & State & $\begin{array}{c}\text { State } \\
\text { Management } \\
\text { Plan }\end{array}$ & $\begin{array}{l}\text { Annual } \\
\text { Application } \\
\text { Package }\end{array}$ \\
\hline Alabama & & $x$ & Nebraska & $x$ & \\
\hline Alaska & $x$ & & Nevada & $x$ & \\
\hline Arizona & $x$ & & New Hampshire & $x$ & \\
\hline Arkansas & & $\mathrm{X}$ & New Jersey & $x$ & \\
\hline California & $x$ & & New Mexico & $x$ & \\
\hline Colorado & $x$ & & New York & & $x$ \\
\hline Connecticut & & $x$ & North Carolina & $x$ & \\
\hline Delaware & & $x$ & North Dakota & $x$ & \\
\hline Florida & & $x$ & Ohio & $x$ & \\
\hline Georgia & $x$ & & Oklahoma & & Request $^{1}$ \\
\hline Hawaii & & $X$ & Oregon & $x$ & \\
\hline Idaho & $x$ & & Pennsylvania & $x$ & \\
\hline Illinois & & $x$ & Rhode Island & $x$ & \\
\hline Indiana & $x$ & & South Carolina & $X$ & \\
\hline Iowa & $x$ & & South Dakota & $X$ & \\
\hline Kansas & $x$ & & Tennessee & $x$ & \\
\hline Kentucky & $x$ & & Texas & & $x$ \\
\hline Louisiana & & $x$ & Utah & $x$ & \\
\hline Maine & $x$ & & Vermont & $x$ & \\
\hline Maryland & & $X$ & Virginia & & $x$ \\
\hline Massachusetts & & $x$ & Washington & $x$ & \\
\hline Michigan & $X$ & & West Virginia & $x$ & \\
\hline Minnesota & & $x$ & Wisconsin & & $x$ \\
\hline Mississippi & $x$ & & Wyoming & $X$ & \\
\hline Missouri & $x$ & & District of Columbia & $x$ & \\
\hline Montana & $\mathrm{X}$ & & & & \\
\hline
\end{tabular}

Source: State Management Plans and Annual Application Manuals accessed online from state websites.

${ }^{1}$ Oklahoma posts general program guidelines with a link to request an official application form.

The state agency designated by the chief executive officer of the state has principal authority and responsibility for administering the Section 5310 program, and it identifies the local government authorities eligible to apply for Section 5310 funds as coordinators of service for elderly persons and persons with disabilities. Table 12 details the designated Section 5310 program administrators for each state. The Department of Transportation was designated the Section 5310 administrator in Florida and all other states, including the District of Columbia, with the exception of Georgia, Oklahoma, and Maryland. In Georgia and Oklahoma, the Department of Human Services (DHS) administers the Section 5310 program. The designated Section 5310 administrator in Maryland is the State of Maryland Interagency Committee on Specialized Transportation (ICST). 
Table 12 Section 5310 Administrator

\section{Program Administrator}

Alabama Department of Transportation (ALDOT)

Alaska Department of Transportation (AkDOT)

Arizona Department of Transportation (ADOT)

Arkansas State Highway and Transportation Department (AHTD)

California Department of Transportation (Caltrans)

Colorado Department of Transportation (CDOT)

Connecticut Department of Transportation (ConnDOT)

Delaware Department of Transportation (DeIDOT)

Florida Department of Transportation (FDOT)

Georgia Department of Human Services (DHS)

Hawaii State Department of Transportation (HDOT)

Idaho Transportation Department (ITD)

Illinois Department of Transportation (IDOT)

Indiana Department of Transportation (INDOT)

Iowa Department of Transportation (Iowa DOT)

Kansas Department of Transportation (KDOT)

Kentucky Transportation Cabinet/Office of Transportation (KYTC/OTD)

Louisiana Department of Transportation and Development (DOTD)

Maine State Department of Transportation (MaineDOT)

State of Maryland Interagency Committee on Specialized Transportation (ICST)

Massachusetts Department of Transportation (MassDOT)

Michigan Department of Transportation (MDOT)

Minnesota Department of Transportation (MnDOT)

Mississippi Department of Transportation (MDOT)

Missouri Department of Transportation (MoDOT)

Montana Department of Transportation (MDT)

Nebraska Department of Roads (NDOR)

Nevada Department of Transportation (NDOT)

New Hampshire Department of Transportation (NHDOT)

New Jersey Transit Corporation (NJ Transit)

New Mexico Department of Transportation (NMDOT)

New York State Department of Transportation (NYSDOT)

North Carolina Department of Transportation (NCDOT)

North Dakota Department of Transportation (NDDOT)

Ohio Department of Transportation (ODOT)

Oklahoma Department of Human Services (OKDHS)

Oregon Department of Transportation (ODOT) Public Transit Division (PTD)

Pennsylvania Department of Transportation (PENNDOT)

Rhode Island Public Transit Authority (RIPTA)

South Carolina Department of Transportation (SCDOT)

South Dakota Department of Transportation (SDDOT)

Tennessee Department of Transportation (TDOT) MTR

Texas Department of Transportation (TxDOT)

Utah Department of Transportation (UDOT)

Vermont Agency of Transportation (VTrans)

Virginia Department of Rail and Public Transportation (DRPT)

Washington Department of Transportation (WSDOT)

West Virginia Department of Transportation (WVDOT)

Wisconsin Department of Transportation (WisDOT)

Wyoming Department of Transportation (WYDOT)

District of Columbia District Department of Transportation (DDOT) 


\section{Administrative Requirements}

Many of the designated state departments of transportation assign a division or an office within the department to receive the Section 5310 funds apportioned to the state, and to apply to FTA for these funds on behalf of private nonprofit agencies and eligible local governmental authorities within the state. Assignment of responsibility for program administration for each of the states is summarized in Table 13. Assignment of program administration to the state's public transit office is most common (54.9\%), followed by assignment to the state department of transportation (25.5\%). Florida's Public Transit Office serves as the program administrator for Section 5310 funds within Florida.

Table 13 Section 5310 Program Administration

\begin{tabular}{ll}
\hline Program Administration & \multicolumn{1}{c}{ States } \\
\hline Department of Transportation & AL, AK, AR, CO, DE, IL, NE, NV, NY, VA, WA, WI, WY \\
& $\mathrm{CA}, \mathrm{FL}, \mathrm{ID}, \mathrm{IN}, \mathrm{IA}, \mathrm{KS}, \mathrm{LA}, \mathrm{MD}, \mathrm{MA}, \mathrm{MI}, \mathrm{MN}, \mathrm{MS}, \mathrm{MT}, \mathrm{NH}$, \\
Public Transit Office & $\mathrm{NJ}, \mathrm{MN}, \mathrm{NC}, \mathrm{OH}, \mathrm{OR}, \mathrm{PA}, \mathrm{RI}, \mathrm{SC}, \mathrm{SD}, \mathrm{TX}, \mathrm{UT}, \mathrm{VT}, \mathrm{WV}, \mathrm{DC}$ \\
& $\mathrm{AZ}, \mathrm{HI}, \mathrm{ME}$ \\
Statewide/Multimodal Planning Division & $\mathrm{CO}, \mathrm{TN}$ \\
Division of Transportation Development & $\mathrm{GA}$ \\
Department of Human Resources & $\mathrm{KY}$ \\
Office of Transportation Delivery & $\mathrm{MO}$ \\
Multimodal Operations Division & $\mathrm{ND}$ \\
Local Government Division & $\mathrm{OK}$ \\
Aging Services Division &
\end{tabular}

The Section 5310 program administrator is responsible for the following:

- Document the state's procedures in a State Management Plan (SMP)

- Notify eligible local entities of funding availability

- Plan for future transportation needs and ensure integration and coordination among diverse transportation modes and providers

- Solicit applications, develop project selection criteria, and review and select projects for approval

- Forward an annual Program of Projects (POP) and grant application to FTA

- Certify that allocations of grants to subrecipients are distributed on a fair and equitable basis

- Certify eligibility of applicants and project activities

- Ensure compliance with federal requirements by all subrecipients

- Certify that all projects are derived from a locally developed, coordinated public transit-human services transportation plan, developed through a process involving representatives of public, private, and nonprofit transportation and human services

- Monitor local project activity

- Oversee project audit and closeout 
The program administrator must ensure not only that local applicants and project activities are eligible, but also that they are in compliance with federal requirements. In addition, the program administrator is required to ensure that private for-profit transportation providers are afforded an opportunity to participate to the maximum extent feasible, and that the program coordinates transportation services assisted under Section 5310 with transportation services assisted by other federal sources. All program activities must be included in the Statewide Transportation Improvement Program (STIP). After FTA approval of the application, funds are made available for state administration and for allocation to individual subrecipients within the state.

FTA headquarters in Washington, D.C., provides overall policy and program guidance for the Section 5310 program; apportions funds annually to the states; develops and implements financial management procedures; initiates and manages program support activities; and, conducts national program reviews and evaluations. FTA regional offices are responsible for the day-to-day administration of the program that involves review and approval of state grant applications; obligation of funds; management of grants; and oversight of the state's implementation of the annual program, including revisions to the POP. Regional offices also receive state certifications; review and approve SMPs; provide technical assistance, advice, and guidance to the states as needed; and, perform state management reviews through a contractor every three years, or as circumstances warrant. FTA completes other reviews as necessary.

\section{Federal/Local Matching Requirements}

The federal share of eligible Section 5310 capital costs may not exceed 80 percent of the net cost of the activity. An amount up to 10 percent is eligible to fund program administrative costs including administration, planning, and technical assistance. The local share of eligible capital costs may not be less than 20 percent of the net cost of the activity, and may be provided from an undistributed cash surplus, a replacement or depreciation cash fund or reserve, a service agreement with a state or local service agency or private social service organization, or new capital.

A total of 35 states (68.6\%) require subrecipients to follow a federal/local match of $80 / 20$, while the remaining 16 states (31.4\%) require compliance with a maximum federal match of 80 percent, but have established a different percent for the local match. Each state's federal/local match is detailed in Table 14. Arizona requires that subrecipients provide a 20 percent local match plus an additional one percent of the total procurement cost of the capital equipment. Both California and Massachusetts reduce the local match through the use of Transportation Development Credits (toll credits). California uses a set local match of 11.47 percent, while Massachusetts covers up to 20 percent, depending upon funding availability. Connecticut will provide a maximum local match in the amount of $\$ 40,000$ with the subrecipient responsible for the remaining balance. Idaho and Illinois provide the local match (up to $20 \%$ ) depending on availability of funds. Florida, Tennessee, Vermont, and Kentucky provide the subrecipient with half of the local match $(10 \%)$, and Kentucky will cover the entire local match if sufficient funds are available. Delaware and Michigan provide the entire 20 percent local match to subrecipients. Montana, North Carolina, and Oregon participate in the Seven-State Pilot Program that uses a sliding scale that effectively reduces 
the local match to 14 percent for subrecipients in Montana and North Carolina and 10.27 percent for subrecipients in Oregon.

Table 14 Federal/Local Match

\begin{tabular}{lcc|lcc}
\hline State & $\begin{array}{c}\text { Federal } \\
\text { Match }\end{array}$ & $\begin{array}{c}\text { Local } \\
\text { Match }\end{array}$ & State & $\begin{array}{c}\text { Federal } \\
\text { Match }\end{array}$ & $\begin{array}{c}\text { Local } \\
\text { Match }\end{array}$ \\
\hline Alabama & $80 \%$ & $20 \%$ & Nebraska & $80 \%$ & $20 \%$ \\
Alaska & $80 \%$ & $20 \%$ & Nevada & $80 \%$ & $20 \%$ \\
Arizona & $80 \%$ & $20 \%+1 \%^{1}$ & New Hampshire & $80 \%$ & $20 \%$ \\
Arkansas & $80 \%$ & $20 \%$ & New Jersey & $80 \%$ & $20 \%$ \\
California & $88.53 \%$ & $11.47 \%^{2}$ & New Mexico & $80 \%$ & $20 \%$ \\
Colorado & $80 \%$ & $20 \%$ & New York & $80 \%$ & $20 \%$ \\
Connecticut & $80 \%$ & $0-20 \%^{3}$ & North Carolina & $80 \%$ & $10 \%{ }^{4}$ \\
Delaware & $80 \%$ & $0 \%$ & North Dakota & $80 \%$ & $20 \%$ \\
Florida & $80 \%$ & $10 \%$ & Ohio & $80 \%$ & $20 \%$ \\
Georgia & $80 \%$ & $20 \%$ & Oklahoma & $83 \%$ & $17 \%$ \\
Hawaii & $80 \%$ & $20 \%$ & Oregon & $89.73 \%$ & $10.27 \%$ \\
Idaho & $80 \%$ & $0-20 \%$ & Pennsylvania & $80 \%$ & $20 \%$ \\
Illinois & $80 \%$ & $0-20 \%$ & Rhode Island & $80 \%$ & $20 \%$ \\
Indiana & $80 \%$ & $20 \%$ & South Carolina & $80 \%$ & $20 \%$ \\
Iowa & $80 \%$ & $20 \%$ & South Dakota & $80 \%$ & $20 \%$ \\
Kansas & $80 \%$ & $20 \%$ & Tennessee & $80 \%$ & $10 \%$ \\
Kentucky & $80 \%$ & $10-20 \%$ & Texas & $80 \%$ & $20 \%$ \\
Louisiana & $80 \%$ & $20 \%$ & Utah & $80 \%$ & $20 \%$ \\
Maine & $80 \%$ & $20 \%$ & Vermont & $80 \%$ & $10 \%$ \\
Maryland & $80 \%$ & $20 \%$ & Virginia & $80 \%$ & $20 \%$ \\
Massachusetts & $80 \%$ & $0-20 \%{ }^{2}$ & Washington & $80 \%$ & $20 \%$ \\
Michigan & $80 \%$ & $0 \%$ & West Virginia & $80 \%$ & $20 \%$ \\
Minnesota & $80 \%$ & $20 \%$ & Wisconsin & $80 \%$ & $20 \%$ \\
Mississippi & $80 \%$ & $20 \%$ & Wyoming & $80 \%$ & $20 \%$ \\
Missouri & $80 \%$ & $20 \%$ & District of Columbia & $80 \%$ & $20 \%$ \\
Montana & $86 \%$ & $14 \%{ }^{4}$ & & & \\
\hline Subrecipient respon & & & &
\end{tabular}

${ }^{1}$ Subrecipient responsible for an additional $1 \%$ of total vehicle procurement cost

${ }^{2}$ Toll credits available to reduce share

${ }^{3}$ FTA grant amount shall not exceed $\$ 40,000$, subrecipient pays remaining balance

${ }^{4}$ Pilot Program sliding scale rate

\section{State Administrative Expenses}

Up to 10 percent of the state's total fiscal year (FY) apportionment may be used to fund program administration costs including administration, planning, and technical assistance. Administrative costs by state are presented in Table 15. A total of 27 states (52.9\%) acknowledged use of state administrative expenses at the maximum allowable rate of 10 percent. No reference to the rate of state administrative costs was found for 16 states (31.4\%). Iowa, Michigan, and Pennsylvania reported that they did not use the allowable 10 percent of the apportionment. By California state law, California may not use more than 5 percent for administrative costs. Kansas reported the use of 15 percent, a rate higher than that allowed. Louisiana, Nebraska, and Oregon use the greater of $\$ 25,000$, or 10 percent. SMPs indicated that state administrative funds were most often used to cover program administration costs, procurement procedures, and training. 
Table 15 State Administrative Expenses

\begin{tabular}{|c|c|c|c|}
\hline State & $\begin{array}{c}\text { State } \\
\text { Administrative } \\
\text { Costs }\end{array}$ & State & $\begin{array}{c}\text { State } \\
\text { Administrative } \\
\text { Costs }\end{array}$ \\
\hline Alabama & $10 \%$ & Nebraska & $>$ of $\$ 25,000 / 10 \%$ \\
\hline Alaska & $10 \%$ & Nevada & $10 \%$ \\
\hline Arizona & $10 \%$ & New Hampshire & $10 \%$ \\
\hline Arkansas & NR & New Jersey & $10 \%$ \\
\hline California & $5 \%$ & New Mexico & NR \\
\hline Colorado & $10 \%$ & New York & NR \\
\hline Connecticut & NR & North Carolina & $10 \%$ \\
\hline Delaware & NR & North Dakota & $10 \%$ \\
\hline Florida & NR & Ohio & $10 \%$ \\
\hline Georgia & NR & Oklahoma & NR \\
\hline Hawaii & NR & Oregon & $>$ of $\$ 25,000 / 10 \%$ \\
\hline Idaho & $10 \%$ & Pennsylvania & $0 \%$ \\
\hline Illinois & $10 \%$ & Rhode Island & $10 \%$ \\
\hline Indiana & $10 \%$ & South Carolina & $10 \%$ \\
\hline Iowa & $0 \%$ & South Dakota & NR \\
\hline Kansas & $15 \%$ & Tennessee & $10 \%$ \\
\hline Kentucky & $10 \%$ & Texas & $10 \%$ \\
\hline Louisiana & $>$ of $\$ 25,000 / 10 \%$ & Utah & $10 \%$ \\
\hline Maine & $10 \%$ & Vermont & NR \\
\hline Maryland & NR & Virginia & NR \\
\hline Massachusetts & $10 \%$ & Washington & NR \\
\hline Michigan & $0 \%$ & West Virginia & $10 \%$ \\
\hline Minnesota & $10 \%$ & Wisconsin & NR \\
\hline Mississippi & $10 \%$ & Wyoming & $10 \%$ \\
\hline Missouri & $10 \%$ & District of Columbia & NR \\
\hline Montana & $10 \%$ & & \\
\hline
\end{tabular}

NR indicates no reference to state administrative costs in the State Management Plan

\section{Vehicle Useful Life and Replacement Standards}

The Common Grant Rule gives states flexibility in managing and disposing of equipment. In keeping with the intent of the rule, FTA does not apply its policies regarding useful life standards for vehicles, vehicle replacement, or the requirement to use the straight-line depreciation method for determining fair market value and FTA reimbursement to Section 5310. Rather, FTA requires states to establish and implement their own rolling stock requirements for all categories of vehicles acquired under the Section 5310 program, consistent with the state's standards for equipment purchased with state funds. FTA permits state grantees to do the following:

1. Establish their own minimum useful life standards for vehicles.

2. Use their own procedures for determining fair market value.

3. Develop their own policies and procedures for maintenance and replacement of vehicles; however, maintenance requirements and insurance coverage must be adequate to protect the federal interest in the vehicle within the useful life determined by the state. 
Researchers examined useful life standards detailed by states in SMPs and annual application manuals. Using Florida useful life as a standard, like vehicles from other states were identified and compared to Florida in terms of years and miles of useful life (Table 16).

Table 16 Vehicle Useful Life Years/Mileage

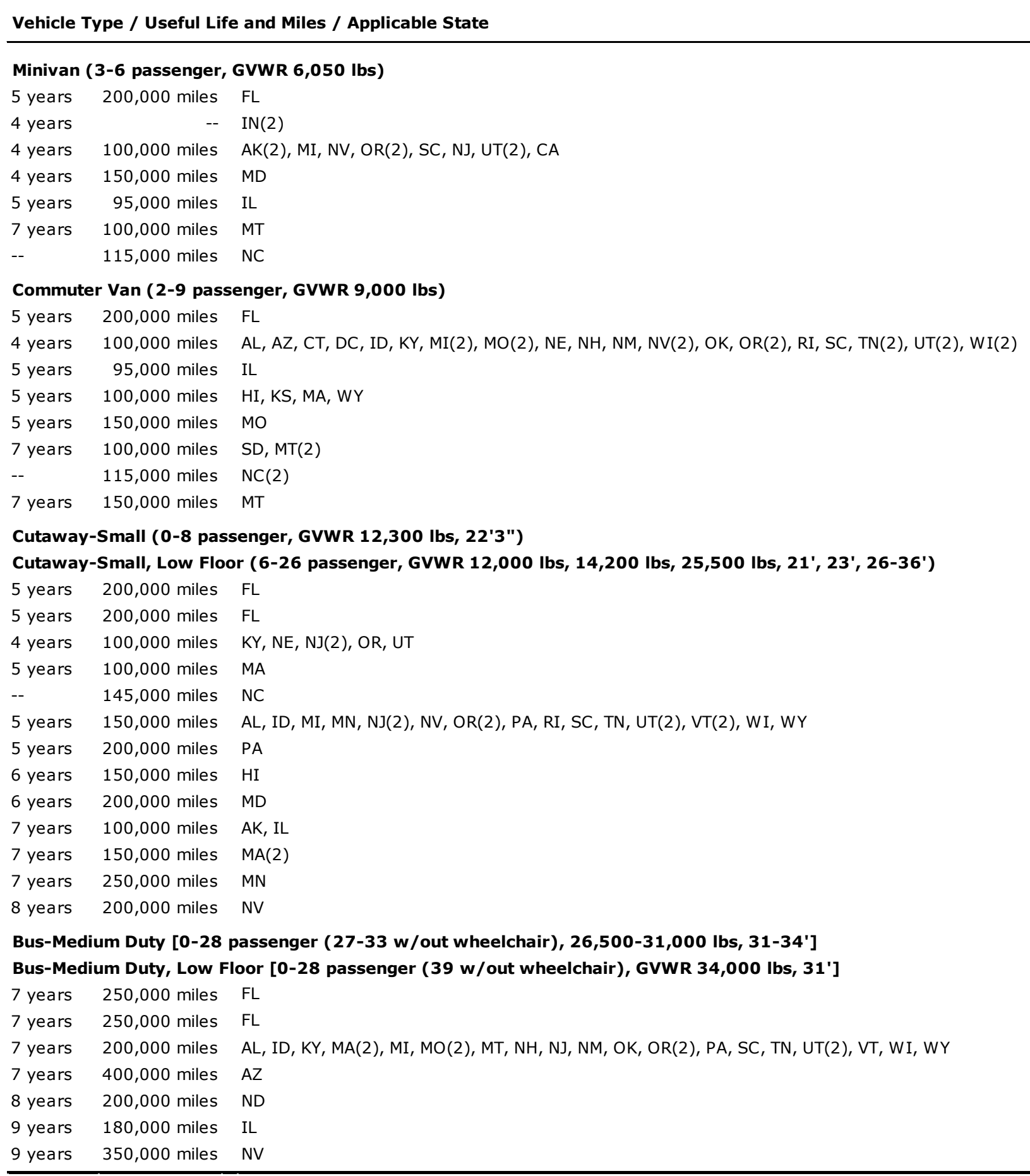


The comparison was carried out by looking at the sample means of Florida vehicles versus all other states vehicles and using mean comparison tests. The tests indicate that vehicles administered under the TRIPS program had a longer useful life when compared to the outof-state sample presented in Table 6.

\section{Procurement and Specifications}

When procuring property, supplies, equipment, or services under an FTA grant, a state is required to follow the same policies and procedures it uses for procurements from its nonfederal funds, to the extent permitted by federal statutes and regulations. While the federal threshold for small purchases is currently $\$ 100,000$, for itself and its subrecipients, a state may set a threshold lower than the federal threshold. All governmental subrecipients may follow state procurement procedures; however, FTA third-party contracting requirements are fewer for states and subrecipients that are local or tribal governments than for subrecipients that are private nonprofit organizations because of differences between 49 CFR Part 18 and 49 CFR Part 19. A state may choose to use the more detailed FTA requirements included in the current FTA Circular 4220.1 for all subrecipients as part of its state procurement procedures for the sake of consistency.

Procurement procedures used by states and their public agencies and instrumentalities must comply with the following specific federal procurement requirements:

- State procurement practices must, at a minimum, comply with five specific federal requirements: (1) for rolling stock, a five-year limitation on contract period of performance; (2) full and open competition; (3) a prohibition against geographic preferences; (4) the use of the Brooks Act procedures for procurement of architectural and engineering services, if the state has not adopted a statute governing procurement of such services; and (5) inclusion in contracts of all federal clauses required by federal statutes and executive orders and their implementing regulations.

- Subrecipients that are governmental authorities such as local or Indian tribal governments must comply with the same federal requirements governing state procurements. States are responsible for ensuring that subrecipients are aware of and comply with federal requirements.

- Subrecipients that are private nonprofit organizations must comply with FTA procurement requirements contained in the current FTA Circular 4220.1. States are responsible for ensuring that private nonprofit subrecipients are aware of and comply with these additional requirements.

Responsibility for vehicle procurement and development of specifications for each state is presented in Table 17. The majority of procurements are processed at the state level, often through the use of a state contract, and while many states do allow subrecipients to establish their own procurement processes, subrecipients are most always subject to state oversight and approval prior to actual procurement.

Georgia restricts the use of Section 5310 funds to the purchase of service rather than the purchase of vehicles. Florida appears to be the only state that requires a second level of 
safety testing for compliance with established FDOT Crash and Safety Testing Standards. In Iowa, subrecipients are given the option to procure capital items themselves, join with their peers in consortium procurements, or to defer to the state in a statewide procurement. Iowa reported that in recent years, the predominant mode of procurement had been consortia procurements, with different systems taking the lead on behalf of their peers; however, that process appears to have become more burdensome of late, which has resulted in a move to statewide procurements. Oversight and technical assistance are provided by Office of Public Transportation staff.

In Vermont, all Section 5310 vehicle procurements are completed by a designated 5311 transportation organization. Oversight is conducted by the Vermont Agency of Transportation (VTrans). Subrecipients must certify by way of a checklist that all federal clauses were included in the procurement and return a copy certifying compliance. VTrans must provide written approval of the procurement manual prior to purchase.

Table 17 Section 5310 Responsibility for Procurement and Specifications

\begin{tabular}{|c|c|c|}
\hline State & Procurement & Specifications \\
\hline Alabama & $\begin{array}{l}\text { ALDOT \& Alabama Finance Department } \\
\text { competitive bidding process }\end{array}$ & ALDOT \\
\hline Alaska & $\begin{array}{l}\text { Alaska Transit Office state contract; } \\
\text { subrecipient can procure }\end{array}$ & Alaska Transit Office \\
\hline Arizona & $\begin{array}{l}\text { ADOT Multimodal Planning Division (MPD) } \\
\text { procures, but requires payment well in } \\
\text { advance of delivery }\end{array}$ & ADOT \\
\hline Arkansas & $\begin{array}{l}\text { AHTD purchases all vehicle through state } \\
\text { procurement process }\end{array}$ & AHTD \\
\hline California & $\begin{array}{l}\text { Caltrans Division of Mass Transportation } \\
\text { (DMT) issues vehicle purchase orders } \\
\text { based on Caltrans DMT-approved vehicles }\end{array}$ & Caltrans DMT \\
\hline Colorado & $\begin{array}{l}\text { Colorado Department of Transportation } \\
\text { (CDOT); reimbursement upon receipt of } \\
\text { the Certificate of Procurement and } \\
\text { Acceptance by CDOT }\end{array}$ & CDOT \\
\hline Connecticut & $\begin{array}{l}\text { Greater New Haven Transit District } \\
\text { (GNHTD) contract once a year; may } \\
\text { purchase on own with ConnDOT approval }\end{array}$ & GNHTD \\
\hline Delaware & Delaware Transit Corporation (DTC) & DTC \\
\hline Florida & $\begin{array}{l}\text { Transit Research Inspection Procurement } \\
\text { Services (TRIPS); proposer must meet } \\
\text { approval requirements of FDOT Crash and } \\
\text { Safety Testing Standards; award of } \\
\text { contract is contingent upon successful } \\
\text { completion of a two-step pre-approval } \\
\text { process and obtaining a Temporary Waiver } \\
\text { Contract }\end{array}$ & TRIPS \\
\hline
\end{tabular}


Table 17 Section 5310 Responsibility for Procurement and Specifications continued

\begin{tabular}{|c|c|c|}
\hline State & Procurement & Specifications \\
\hline Georgia & $\begin{array}{l}\text { Georgia Department of Human Services } \\
\text { (DHS); no program funds used to purchase } \\
\text { vehicles; purchase of service only }\end{array}$ & DHS \\
\hline Hawaii & $\begin{array}{l}\text { Hawaii State Department of Transportation } \\
\text { (HDOT) will procure upon receipt of } \\
\text { subrecipient's documents; subrecipient } \\
\text { may procure using an HDOT-approved } \\
\text { process }\end{array}$ & $\begin{array}{l}\text { Subrecipient with HDOT } \\
\text { assistance or use List of Vehicle } \\
\text { Vendors }\end{array}$ \\
\hline Idaho & $\begin{array}{l}\text { Idaho Transportation Department (ITD) } \\
\text { ensures that all procurements comply with } \\
\text { state law; reviews bid documents }\end{array}$ & $\begin{array}{l}\text { ITD reviews after subrecipient } \\
\text { prepares }\end{array}$ \\
\hline Illinois & $\begin{array}{l}\text { IDOT \& Department of Central } \\
\text { Management procure all vehicles through } \\
\text { Consolidate Vehicle Procurement Program } \\
\text { (CVP) }\end{array}$ & IDOT uses a consultant \\
\hline Indiana & $\begin{array}{l}\text { INDOT procures all vehicles through } \\
\text { Indiana Department of Administration } \\
\text { (INDOA) Quantity Purchase Awards (QPA); } \\
\text { applicants select vehicles from INDOT's } \\
\text { Vehicle Selection Guide }\end{array}$ & INDOT \\
\hline Iowa & $\begin{array}{l}\text { Statewide procurement or consortium of } \\
\text { peers conducts procurement; consortium } \\
\text { use has increased }\end{array}$ & $\begin{array}{l}\text { Office of Public Transit (OPT) } \\
\text { approves }\end{array}$ \\
\hline Kansas & $\begin{array}{l}\text { Kansas Department of Transportation } \\
\text { (KDOT) does not order or purchase } \\
\text { vehicles }\end{array}$ & $\begin{array}{l}\text { Kansas Coordinated Transit } \\
\text { District Council (KCTDC) in } \\
\text { conjunction with KDOT }\end{array}$ \\
\hline Kentucky & $\begin{array}{l}\text { Kentucky Transportation Cabinet (KYTC) } \\
\text { Office of Transportation (OTD) does not } \\
\text { purchase vehicles directly; subrecipient can } \\
\text { purchase off state contract with KYTC/OTD } \\
\text { approval prior to using any state price } \\
\text { contract or joint bid through the Kentucky } \\
\text { Public Transit Association (KPTA) }\end{array}$ & KPTA \\
\hline Louisiana & $\begin{array}{l}\text { Louisiana Department of Transportation } \\
\text { and Development (DOTD) forwards bid } \\
\text { request to Division of Administration for } \\
\text { centralized purchasing }\end{array}$ & $\begin{array}{l}\text { DOTD develops specifications for } \\
\text { equipment most often requested; } \\
\text { subrecipient must provide } \\
\text { specifications for other vehicles }\end{array}$ \\
\hline Maine & $\begin{array}{l}\text { Maine Department of Transportation } \\
\text { (MaineDOT) Bureau of Purchases processes } \\
\text { all bid awards and purchases all vehicles }\end{array}$ & $\begin{array}{l}\text { Bureau of Transportation } \\
\text { Systems Planning sponsoring } \\
\text { peer group for input in the } \\
\text { specification development } \\
\text { process }\end{array}$ \\
\hline
\end{tabular}


Table 17 Section 5310 Responsibility for Procurement and Specifications continued

\begin{tabular}{|c|c|c|}
\hline State & Procurement & Specifications \\
\hline Maryland & $\begin{array}{l}\text { Maryland Transit Administration (MTA) } \\
\text { state contract }\end{array}$ & MTA \\
\hline Massachusetts & $\begin{array}{l}\text { Massachusetts Department of } \\
\text { Transportation (MassDOT) Community } \\
\text { Transit Grant Program (CTP) responsible } \\
\text { for procurement; subrecipient can use own } \\
\text { process or use another transportation } \\
\text { provider's process with MassDOT approval }\end{array}$ & CTP \\
\hline Michigan & $\begin{array}{l}\text { Michigan Department of Management and } \\
\text { Budget conducts vehicle procurements } \\
\text { through the Extended Purchase Program; } \\
\text { subrecipient may procure directly subject } \\
\text { to MDOT review and approval }\end{array}$ & $\begin{array}{l}\text { Bureau of Public Transportation } \\
\text { (BPT) }\end{array}$ \\
\hline Minnesota & $\begin{array}{l}\text { Minnesota Department of Administration: } \\
\text { Materials Management Division }\end{array}$ & Office of Transit \\
\hline Mississippi & $\begin{array}{l}\text { Mississippi Department of Transportation } \\
\text { (MDOT) routinely conducts a centralized } \\
\text { procurement process at the state level for } \\
\text { vehicles through the Procurement Division; } \\
\text { subrecipients may conduct as long as in } \\
\text { compliance and approved }\end{array}$ & $\begin{array}{l}\text { MDOT Public Transit Division } \\
\text { (PTD) }\end{array}$ \\
\hline Missouri & $\begin{array}{l}\text { Missouri Department of Transportation } \\
\text { (MoDOT) }\end{array}$ & MoDOT \\
\hline Montana & $\begin{array}{l}\text { Montana Transit Section procures through } \\
\text { Purchasing Services Bureau }\end{array}$ & Transit Section staff \\
\hline Nebraska & $\begin{array}{l}\text { Nebraska Department of Roads (NDOR) } \\
\text { and the Nebraska Department of } \\
\text { Administrative Services (NDAS) }\end{array}$ & NDOR and NDAS \\
\hline Nevada & $\begin{array}{l}\text { State Purchasing Division conducts for } \\
\text { Nevada Department of Transportation } \\
\text { (NDOT) }\end{array}$ & $\begin{array}{l}\text { NDOT and State Purchasing } \\
\text { Division }\end{array}$ \\
\hline New Hampshire & $\begin{array}{l}\text { New Hampshire Department of } \\
\text { Transportation (NHDOT); subrecipient may } \\
\text { procure }\end{array}$ & NHDOT \\
\hline New Jersey & $\begin{array}{l}\text { New Jersey Transit Corporation (NJ } \\
\text { Transit) purchases all vehicles }\end{array}$ & NJ Transit \\
\hline
\end{tabular}


Table 17 Section 5310 Responsibility for Procurement and Specifications continued

\begin{tabular}{|c|c|c|}
\hline State & Procurement & Specifications \\
\hline New Mexico & $\begin{array}{l}\text { Transit and Rail Division forwards approved } \\
\text { specifications to New Mexico Department } \\
\text { of Transportation (NMDOT) for review and } \\
\text { submission to the State Procurement } \\
\text { Office; bids are opened by the General } \\
\text { Services Division; subrecipients may } \\
\text { purchase on their own or on the State Price } \\
\text { Agreement }\end{array}$ & $\begin{array}{l}\text { Transit and Rail Division develops } \\
\text { and forwards specifications to } \\
\text { subrecipients for review and } \\
\text { applicable comments are } \\
\text { incorporated }\end{array}$ \\
\hline New York & $\begin{array}{l}\text { New York State Department of } \\
\text { Transportation (NYSDOT) Public } \\
\text { Transportation Bureau procures under } \\
\text { statewide Office of General Services (OGS) } \\
\text { Bus Procurement Contract }\end{array}$ & $\begin{array}{l}\text { NYSDOT Public Transportation } \\
\text { Bureau }\end{array}$ \\
\hline North Carolina & $\begin{array}{l}\text { Subrecipient required to procure on own in } \\
\text { compliance with state and federal } \\
\text { guidelines; North Carolina Department of } \\
\text { Transportation (NCDOT) Public Transit } \\
\text { Division (PTD) reviews all procurements }\end{array}$ & $\begin{array}{l}\text { PTD must review and approve all } \\
\text { specifications prior to bid }\end{array}$ \\
\hline North Dakota & $\begin{array}{l}\text { Subrecipient may use "state bid" contract } \\
\text { or may purchase on own, but must comply } \\
\text { to receive reimbursement }\end{array}$ & $\begin{array}{l}\text { North Dakota Department of } \\
\text { Transportation (NDDOT) }\end{array}$ \\
\hline Ohio & $\begin{array}{l}\text { Ohio Department of Transportation (ODOT) } \\
\text { Office of Equipment Management prepares } \\
\text { bid procedures; the Office of Contracts } \\
\text { conducts the bid process; Vehicle Selection } \\
\text { Guide is updated biannually }\end{array}$ & $\begin{array}{l}\text { ODOT Office of Equipment } \\
\text { Management prepares all vehicle } \\
\text { specifications }\end{array}$ \\
\hline Oklahoma & Oklahoma Department of Central Services & $\begin{array}{l}\text { Oklahoma Department of Central } \\
\text { Services }\end{array}$ \\
\hline Oregon & $\begin{array}{l}\text { Subrecipients order vehicles through State } \\
\text { Price Agreements administered by the } \\
\text { Oregon Department of Administrative } \\
\text { Services (DAS); RFP must be approved by } \\
\text { the Public Transit Division (PTD) prior to } \\
\text { signing with vendor; piggybacking is } \\
\text { allowed }\end{array}$ & $\begin{array}{l}\text { DAS and ODOT procurement and } \\
\text { PTD staff prepare specifications }\end{array}$ \\
\hline Pennsylvania & $\begin{array}{l}\text { Subrecipient can use state vehicle } \\
\text { contract; procurements are reviewed by } \\
\text { program management personnel and } \\
\text { Bureau of Public Transportation (BPT) } \\
\text { engineering staff for compliance with state } \\
\text { and federal regulations }\end{array}$ & BPT \\
\hline
\end{tabular}


Table 17 Section 5310 Responsibility for Procurement and Specifications continued

\begin{tabular}{|c|c|c|}
\hline State & Procurement & Specifications \\
\hline Rhode Island & $\begin{array}{l}\text { All major capital purchases are completed } \\
\text { by the Rhode Island Public Transit } \\
\text { Authority (RIPTA); vehicles will be } \\
\text { operated by RIPTA or leased to outside } \\
\text { agencies based on Coordinated Plan }\end{array}$ & RIPTA \\
\hline South Carolina & $\begin{array}{l}\text { Subrecipient purchases off state contract } \\
\text { issued by the South Carolina Office of } \\
\text { Materials Management }\end{array}$ & Office of Public Transit \\
\hline South Dakota & $\begin{array}{l}\text { Office of Procurement Management under } \\
\text { the Bureau of Administration secures } \\
\text { statewide contracts for state and local } \\
\text { agencies to purchase items }\end{array}$ & $\begin{array}{l}\text { South Dakota Department of } \\
\text { Transportation (SDDOT) }\end{array}$ \\
\hline Tennessee & $\begin{array}{l}\text { Generally, all vehicles are purchased } \\
\text { through the competitive sealed bid process } \\
\text { through Tennessee Department of General } \\
\text { Services, Division of Purchasing, from the } \\
\text { General Services statewide contract; } \\
\text { subrecipient may procure after approval } \\
\text { from the Division of Multimodal } \\
\text { Transportation Resources (MTR) }\end{array}$ & $\begin{array}{l}\text { MTR and the Tennessee } \\
\text { Department of Transportation's } \\
\text { (TDOT) Division of Central } \\
\text { Services }\end{array}$ \\
\hline Texas & $\begin{array}{l}\text { Subrecipients are required to have a } \\
\text { procurement policy in place that complies } \\
\text { with state and federal regulations; Texas } \\
\text { Department of Transportation (TXDOT) will } \\
\text { provide technical assistance upon request }\end{array}$ & $\begin{array}{l}\text { TXDOT will provide technical } \\
\text { assistance to subrecipient upon } \\
\text { request }\end{array}$ \\
\hline Utah & $\begin{array}{l}\text { Public Transit Team (PTT) awards funds for } \\
\text { purchase of state procured capital } \\
\text { equipment; subrecipient may procure after } \\
\text { approved by PTT }\end{array}$ & PTT develops \\
\hline Vermont & $\begin{array}{l}\text { All Section } 5310 \text { vehicle procurements are } \\
\text { completed by a designated } 5311 \\
\text { transportation organization; oversight is } \\
\text { conducted by Vermont Agency of } \\
\text { Transportation (VTrans), which must } \\
\text { provide written approval of procurement } \\
\text { manual prior to purchase }\end{array}$ & VTrans \\
\hline Virginia & $\begin{array}{l}\text { Department of Rail and Public } \\
\text { Transportation (DRPT) }\end{array}$ & DRPT \\
\hline Washington & $\begin{array}{l}\text { State of Washington Department of } \\
\text { Enterprise Service, Office of State } \\
\text { Procurement, issues a statewide, multi- } \\
\text { vendor, multi-vehicle contract; } \\
\text { subrecipient purchases and Washington } \\
\text { State Department of Transportation } \\
\text { (WSDOT) reimburses }\end{array}$ & $\begin{array}{l}\text { State of Washington Department } \\
\text { of Enterprise Service, Office of } \\
\text { State Procurement, and WSDOT }\end{array}$ \\
\hline
\end{tabular}


Table 17 Section 5310 Responsibility for Procurement and Specifications continued

\begin{tabular}{|c|c|c|}
\hline State & Procurement & Specifications \\
\hline West Virginia & $\begin{array}{l}\text { Division of Public Transit procures through } \\
\text { the State of West Virginia's Purchasing } \\
\text { Division }\end{array}$ & $\begin{array}{l}\text { Division of Public Transit reviews } \\
\text { specifications yearly to ensure } \\
\text { they include the latest } \\
\text { technological development and } \\
\text { are in compliance with federal } \\
\text { regulations }\end{array}$ \\
\hline Wisconsin & $\begin{array}{l}\text { Wisconsin Department of Transportation } \\
\text { (WisDOT) manages the bid process and } \\
\text { purchase of vehicles; subrecipients may } \\
\text { choose vehicles that best meet their needs } \\
\text { from a vehicle list attached to the } \\
\text { application }\end{array}$ & WisDOT \\
\hline Wyoming & $\begin{array}{l}\text { All vehicle procurements are handled } \\
\text { through Wyoming Department of } \\
\text { Transportation (WYDOT) Office of Local } \\
\text { Government Coordination (LGC) and the } \\
\text { Purchasing Department; a Vehicle } \\
\text { Procurement Package is distributed to } \\
\text { vendors for bid; additional technical } \\
\text { assistance is available for procurements } \\
\text { involving } 20 \text { or more vehicles }\end{array}$ & $\begin{array}{l}\text { WYDOT's LGC and the Purchasing } \\
\text { Department }\end{array}$ \\
\hline District of Columbia & DDOT Office of Contracts and Procurement & $\begin{array}{l}\text { Department of Public Works Fleet } \\
\text { Services }\end{array}$ \\
\hline
\end{tabular}

\section{Pre-award and Post-delivery Reviews}

Procurements for vehicles, other than sedans or unmodified vans, must be audited in accordance with 49 CFR Part 663, "Pre-award and Post-delivery Audits of Rolling Stock Purchases." The regulation requires any recipient or subrecipient that purchases rolling stock for use in revenue service with funds obligated after October 24, 1991, to conduct a pre-award and post-delivery review to assure compliance with its bid specifications, Buy America requirements, and Federal Motor Vehicle Safety Standards (FMVSS) requirements, and to complete specific certifications. Purchase of more than 20 vehicles for use in areas under 200,000 in population (more than 10, for large urbanized areas), other than unmodified vans or sedans, requires in-plant inspection. In the case of consolidated state procurements on behalf of multiple subrecipients, the in-plant inspection requirement is triggered only if a single recipient will receive more than 10 or more than 20 vehicles, depending on area size.

An overview of designated responsibility for pre-award and post-delivery audits is presented in Table 8. In a total of 27 of the 50 states (54\%) required to conduct a pre-award audit, the procurement agency conducts and certifies the pre-award audit. Arizona Department of Transportation (ADOT) inspectors review vehicles on the assembly line and test pilot vehicles. ADOT Equipment Services Division inspects vehicles upon shipment to ADOT and 
prior to delivery to subrecipient. Fleet Services Division within the District of Columbia inspects vehicles in a pre-award audit. If the District procures more than 10 vehicles from any single vendor, the District will have a resident inspector present at the manufacturer's final assembly location throughout the manufacturing process. Mississippi Department of Transportation (MDOT) will provide for in-plant inspection when 10 or more vehicles are procured. MDOT requires the subrecipient to comply with and certify pre-award requirements. Missouri Department of Transportation (MoDOT) staff makes the pre-award audit at the manufacturing site. Every vehicle is inspected before delivery to the subrecipient for compliance to specifications and safety standards.

Vendors must present vehicles to New York State Department of Transportation (NYSDOT) inspectors for compliance with specifications, safety requirements, vehicle order, and quality control prior to delivery to subrecipients. A subrecipient must certify to the North Carolina Department of Transportation (NCDOT) that it has conducted a pre-award audit to ensure compliance. Resident inspection is required when purchasing more than 20 buses or modified vans from a single manufacturer. The Ohio Department of Transportation (ODOT) conducts all procurements for vehicles on behalf of Section 5310 subrecipients in accordance with FTA regulation "Pre-award Audit of Rolling Stock Purchases" and the most recent guidance. When necessary, OEM and Office of Transit staff conduct in-plant inspections during the manufacturing process to ensure compliance with specifications and FTA requirements. Rhode Island Public Transit Authority's bid specifications include provisions to ensure compliance, including pre-award reviews, a pre-production meeting, on-line inspections at the assembly plant, and vehicle road tests at the factory. West Virginia Department of Transportation's Division of Public Transit (DPT) may contract and provide a resident inspector at the manufacturing site during production. DPT audits vendor documentation to ensure compliance and receives and reviews the resident inspector's reports. Pursuant to the Florida TRIPS contract, the dealer is required to submit weekly status reports to the TRIPS Database Center, which tracks the progress of each individual vehicle through the procurement and production process. The report is coordinated with the manufacturer's report. In addition, the vehicle manufacturer's compliance is continually monitored by contracted line inspectors at each vehicle production site.

In 19 of the 50 states ( $38 \%$ ) required to conduct a pre-award audit, the subrecipient conducts and certifies the pre-award audit. The Idaho Transportation Department (ITD) reviews the procurement process and the pre-award, but requires the subrecipient to conduct inspections of the equipment during each phase of the vehicle's construction for single purchases of 20 or more. Oregon Department of Transportation requires the subrecipient to certify the pre-award audit to ensure compliance. Resident inspection is required when purchasing more than 20 buses or modified vans from a single manufacturer. Tennessee's Division of Multimodal Transportation Resources (MTR) requires any subrecipient who purchases rolling stock to certify to MTR that is has conducted a pre-award audit to ensure compliance. Vehicles are inspected before delivery to ensure compliance with safety standards and specifications. Resident inspection is required when purchasing more than 20 buses or modified vans from a single manufacturer. 
Post-delivery audits are performed and certified by the procurement agency in 23 of the 50 states (46\%). The Alabama Department of Transportation (ALDOT) facilitates a thorough inspection of vehicles in advance of delivery to subrecipients. ADOT inspects vehicles prior to delivery to subrecipients. District of Columbia Fleet Services Division inspects in postdelivery. If the District procures more than 10 vehicles from any single vendor, it will send a resident inspector to the manufacturer's final assembly facility and will visually inspect and road-test the buses or vans. The Idaho Transportation Department reviews the procurement process and monitors the post-delivery purchaser's requirements and FMVSS compliance as part of a site visit that includes a complete visual inspection and road test to demonstrate that the vehicle meets the contract specifications. Upon receipt of vehicles ordered, the Louisiana Department of Transportation and Development (DOTD) will conduct a postdelivery audit for Buy America, bid specifications, FMVSS, and specific cost information. DOTD will certify that a resident inspector was on-site throughout the manufacturing period and monitored the manufacture of the vehicles for the procurement of 11 or more vehicles. Upon delivery, the Montana Department of Transportation (MDT) Transit Section jointly inspects with subrecipient and vendor. MDT completes a New Vehicle Delivery Inspection Sheet. Upon delivery, the Nebraska Department of Transportation Purchasing Division conducts a post-delivery audit. The New Mexico Rail and Transit Division signs and completes certifications, verifies Vehicle Identification Number (VIN), completes the Visual Inspection Sheet, and obtains a copy of the manufacturer sticker.

Rhode Island PTA bid specifications include provisions to ensure compliance, including postdelivery reviews, inspection of vehicles using a checklist before final acceptance, and placement of the vehicle into service only after final acceptance. After delivery, the West Virginia Division of Public Transit performs a visual inspection and a road test verifying that the equipment was constructed and operates in accordance with bid specifications. In Florida, all vehicles must be delivered to the Springhill Bus Testing and Inspection Facility (SBTIF) located in Tallahassee, Florida, for an inspection scheduled by the TRIPS manager. Deficiencies noted in the TRIPS Pre-delivery Inspection Report conducted on each vehicle at SBTIF are to be completed before delivery to a subrecipient. The dealer is required to submit weekly status reports to the TRIPS Database Center, which tracks the progress of each individual vehicle through the procurement and production process, from receipt of order through delivery and acceptance of each individual vehicle by the agency. The report is coordinated with the manufacturer's report. The dealer is required to provide a vehicle orientation with each vehicle delivered to an agency.

In 23 of the 50 states (46\%) required to conduct a post-delivery audit, the subrecipient conducts and certifies the post-delivery audit. The subrecipient must certify to NCDOT that it has conducted a post-delivery audit to ensure compliance. Visual inspection and road testing are required when purchasing unmodified vans, cars, or 20 or fewer buses. Ohio DOT conducts all procurements for vehicles on behalf of all Section 5310 subrecipients in accordance with FTA regulation "Post-delivery Audit of Rolling Stock Purchases" and the most recent guidance. Upon receipt of the vehicle, the subrecipient is responsible for road testing and checking the operational functions of the vehicle, and providing the Office of Transit with a signed delivery receipt. In Oregon, the subrecipient must certify the postdelivery audit, complete a visual inspection, and conduct a road test for unmodified vans, 
cars, or 20 or fewer buses. Any subrecipient who purchases rolling stock must certify to Tennessee MTR that it has conducted a post-delivery audit to ensure compliance. A visual inspection and road test are required when purchasing unmodified vans, cars, or 20 or fewer buses. Wisconsin requires each subrecipient to conduct or cause to be conducted the requisite post-delivery review and maintain on file the required certifications. The subrecipient must conduct a vehicle inspection and road test to ensure compliance with specifications. All subrecipients are required to certify to the Wyoming Department of Transportation (WYDOT) that they have conducted a post-delivery audit to ensure compliance. Visual inspections and road tests are required upon delivery to ensure compliance with specifications.

Table 18 Pre-Award and Post-Delivery Audits

\begin{tabular}{|c|c|c|c|c|c|}
\hline State & $\begin{array}{c}\text { Pre-Award } \\
\text { Review }\end{array}$ & $\begin{array}{c}\text { Post-Delivery } \\
\text { Review }\end{array}$ & State & $\begin{array}{c}\text { Pre-Award } \\
\text { Review }\end{array}$ & $\begin{array}{c}\text { Post-Delivery } \\
\text { Review }\end{array}$ \\
\hline Alabama & Subrecipient & Subrecipient & Nebraska & NDOR & NDOR \\
\hline Alaska & Subrecipient & Subrecipient & Nevada & State Purchasing & State Purchasing \\
\hline Arizona & ADOT & ADOT & New Hampshire & NHDOT & NHDOT \\
\hline Arkansas & AHDT & AHDT & New Jersey & NJTransit & NJTransit \\
\hline California & Subrecipient & Subrecipient & New Mexico & T\&RD & T\&RD \\
\hline Colorado & Subrecipient & Subrecipient & New York & NYSDOT & NYSDOT $^{5}$ \\
\hline Connecticut & GNHTD & Subrecipient & North Carolina & Subrecipient & Subrecipient \\
\hline Delaware & DTC & DTC & North Dakota & NDDOT & NDDOT \\
\hline Florida $^{1}$ & TRIPS & TRIPS & Ohio & ODOT & Subrecipient \\
\hline Georgia $^{2}$ & Not Applicable & Not Applicable & Oklahoma & No Reference & No Reference \\
\hline Hawaii & HDOT & Subrecipient & Oregon & Subrecipient & Subrecipient \\
\hline Idaho & Subrecipient & ITD & Pennsylvania & Subrecipient & Subrecipient \\
\hline Illinois & IDOT & IDOT & Rhode Island & RIPTA & RIPTA \\
\hline Indiana & IDOA & INDOT & South Carolina & SCDOT \& SR & SCDOT \& SR \\
\hline Iowa & Subrecipient & Subrecipient & South Dakota & SDDOT & SDDOT \\
\hline Kansas & KCTDC & Subrecipient & Tennessee & Subrecipient & Subrecipient \\
\hline Kentucky & Subrecipient & Subrecipient & Texas & No Reference & No Reference \\
\hline Louisiana & DOTD PTS & DOTD PTS & Utah & Subrecipient & Subrecipient \\
\hline Maine & MaineDOT & MaineDOT & Vermont & VTrans & VTrans \\
\hline Maryland & Subrecipient & Subrecipient & Virginia & Subrecipient & Subrecipient \\
\hline Massachusetts & Subrecipient & Subrecipient & Washington & Subrecipient & Subrecipient \\
\hline Michigan & Subrecipient & Subrecipient & West Virginia & DPT & $\mathrm{DPT}$ \\
\hline Minnesota & No Reference & No Reference & Wisconsin & Subrecipient & Subrecipient \\
\hline Mississippi ${ }^{3}$ & MDOT & Subrecipient & Wyoming & Subrecipient & Subrecipient \\
\hline Missouri & MoDOT & MoDOT & District of Columbia & DDOT FSD & DDOT FSD \\
\hline Montana ${ }^{4}$ & MDT & MDT \& SR & & & \\
\hline
\end{tabular}

${ }^{1}$ Florida Spring Hill Inspection Facility

${ }^{2}$ Georgia purchases service rather than vehicles

${ }^{3}$ MDOT provides for in-plant inspection when $\geq 10$ vehicles are procured

${ }^{4}$ Post-delivery inspection is conducted jointly with state and subrecipient

${ }^{5}$ NYSDOT inspectors responsible for post-delivery inspection

\section{Maintenance Plan and Requirements}

Based on SMPs and Annual Application Manuals, subrecipients in all states are required to have a written maintenance plan or documented maintenance procedures with the exception of Delaware, Oklahoma, Rhode Island, and Wisconsin. Oklahoma makes no reference in its online program description, and Wisconsin makes no reference to the requirement in its Annual Application Manual. In Delaware, upon receipt of a vehicle, the 
Delaware Transit Corporation (DTC) will set up a maintenance schedule at one or more of its maintenance locations statewide. Subrecipients are responsible for delivering the vehicle for maintenance and retrieving the vehicle upon completion of the required maintenance. Rhode Island Public Transit Authority (RIPTA) maintains all vehicles purchased with FTA funding for the useful life of the vehicle. The cost of maintenance is the responsibility of the subrecipient.

\section{Preventive Maintenance Requirement}

Preventive maintenance requirements are referenced in most SMPs and annual application manuals and are detailed in Table 19. A total of 26 of the 50 states and the District of Columbia $(51.0 \%)$ require that the subrecipient develop and incorporate a preventive maintenance program that provides a means of indicating the types of inspections, maintenance, and lubrication operations that are to be performed on each vehicle, along with the date or mileage these operations are due. A total of 13 of the 50 states and the District of Columbia (25.5\%) require that the subrecipient meet at least the minimum OEM recommendations for maintenance and preventive maintenance. Ten states $(19.6 \%)$ provide subrecipients with an official Preventive Maintenance Plan. Delaware, Maryland, and South Carolina provide Preventive Maintenance Programs. Florida and Indiana have developed a Preventive Maintenance Manual for subrecipients' use. Illinois provides a Sample Preventive Maintenance Program, which subrecipients can use to establish a specific agency plan. Nebraska distributes a Minimum Preventive Maintenance Plan. Nevada has developed a software maintenance plan for subrecipients' use. Rhode Island created a centralized Preventive Maintenance Plan, specifically for use within its centralized maintenance program.

Table 19 Preventive Maintenance Requirement

\begin{tabular}{ll} 
Preventive Maintenance Program & \multicolumn{1}{c}{ States } \\
\hline Subrecipient PM Program & $\begin{array}{l}\text { AL, AZ, AR, CA, CT, GA, HI, IA, KS, KY, ME, MS, MT, } \\
\mathrm{NH}, \mathrm{NJ}, \mathrm{NM}, \mathrm{NY}, \mathrm{OR}, \mathrm{PA}, \mathrm{SD}, \mathrm{TE}, \mathrm{TX}, \mathrm{UT}, \mathrm{VT}, \mathrm{VA}, \mathrm{WA}\end{array}$ \\
$\begin{array}{l}\text { Minimum Original Equipment Manufacturer (OEM) } \\
\text { Standards }\end{array}$ & $\begin{array}{l}\mathrm{AK}, \mathrm{CO}, \mathrm{DC}, \mathrm{ID}, \mathrm{LA}, \mathrm{MA}, \mathrm{MI}, \mathrm{MN}, \mathrm{MO}, \mathrm{NC}, \mathrm{ND}, \mathrm{WV}, \\
\text { Official State Preventive Maintenance Manual }\end{array}$ \\
$\begin{array}{l}\text { No Reference in SMP or Application } \\
\text { DE, FL, IL, IN, MD, NE, NV, OH, RI, SC }\end{array}$ & $\mathrm{OK}, \mathrm{WI}$ \\
\hline
\end{tabular}

Source: State Management Plans and Annual Application Manuals accessed online

from State websites

\section{Compliance Review Schedule}

Based on information reported in SMPs and annual application manuals, most compliance reviews and/or inspections are conducted every two to three years, as indicated in Table 20. Illinois and West Virginia conduct compliance reviews annually. Illinois inspects a sample of subrecipients each year, while West Virginia inspects 20 percent of West Virginia's subrecipients annually. Delaware inspects all vehicles at Delaware's statewide maintenance facilities. 
Table 20 Compliance Review Schedule

\begin{tabular}{ll} 
Compliance Review/Inspection Schedule & \multicolumn{1}{c}{ States } \\
\hline Annual Review & AZ, DC, KY, MN, SD \\
Every 2 Years & $\mathrm{CO}, \mathrm{FL}, \mathrm{LA}, \mathrm{MT}, \mathrm{NV}, \mathrm{NJ}, \mathrm{NM}, \mathrm{ND}, \mathrm{TX}, \mathrm{UT}, \mathrm{WA}$ \\
Every 3 Years & $\mathrm{AL}, \mathrm{CA}, \mathrm{IN}, \mathrm{KS}, \mathrm{ME}, \mathrm{MI}, \mathrm{MO}, \mathrm{NH}, \mathrm{NC}, \mathrm{OH}, \mathrm{SC}, \mathrm{TN}, \mathrm{VT}$ \\
Every 5 Years & $\mathrm{OR}$ \\
On-site Inspection (frequency not indicated) & $\mathrm{AK}, \mathrm{AR}, \mathrm{GA}, \mathrm{HI}, \mathrm{ID}, \mathrm{IA}, \mathrm{MA}, \mathrm{MD}, \mathrm{MS}, \mathrm{NE}, \mathrm{PA}, \mathrm{WY}$ \\
Sample a Percentage Annually & $\mathrm{IL}, \mathrm{WV}$ \\
Inspection @ Statewide Maintenance Location & $\mathrm{DE}$ \\
No Reference in SMP or Application & $\mathrm{CT}, \mathrm{NY}, \mathrm{OK}, \mathrm{RI}, \mathrm{VA}, \mathrm{WI}$
\end{tabular}

Source: State Management Plans and Annual Application Manuals accessed online

from State websites

\section{Reporting Requirements}

An inventory of all reporting requirements included in SMPs and annual application manuals for all 50 states and the District of Columbia is detailed in Table 21. Quarterly reporting is required in 35 percent of the states, while 20 percent of the states require some type of monthly reporting. Florida, Alabama, and West Virginia have incorporated online reporting, and North Carolina has established an Operating Statistics (OPSTATS) Report that enables subrecipients to identify trends through use of an Excel data tracking form.

Table 21 Reporting Requirements

\begin{tabular}{|c|c|}
\hline State & Reporting Requirements \\
\hline Alabama & $\begin{array}{l}\text { Quarterly Reports / Annual Reports / ALDOT supplied forms / submit online } \\
\text { using Alabama Transit Reporting System (ATRS) }\end{array}$ \\
\hline Alaska & $\begin{array}{l}\text { Road Test, New Vehicle Inspection Form, Quarterly Reports: Operations, } \\
\text { Ridership, Performance, Financial Costs }\end{array}$ \\
\hline Arizona & Vehicle Maintenance Reports \\
\hline Arkansas & Quarterly Performance Monitoring Reports / Fleet PM Program \\
\hline California & $\begin{array}{l}\text { Milestone Progress Report / Semi-annual Form posted on website: trips, } \\
\text { mileage, maintenance costs by vehicle / Report damage or loss within } 10 \text { days }\end{array}$ \\
\hline Colorado & $\begin{array}{l}\text { Reimbursement Requests / Annual Certification and Performance Report } \\
\text { (cost/trip, hour, mile) / Accessibility of Service Compliance / Basic Operating } \\
\text { Data: operating and administrative expenses, one-way trips, service miles, } \\
\text { and service hours }\end{array}$ \\
\hline Connecticut & $\begin{array}{l}\text { Quarterly Operating Report / Quarterly Maintenance Report (maintenance and } \\
\text { repairs) }\end{array}$ \\
\hline Delaware & Monthly Vehicle Utilization Report \\
\hline Florida & Dealer Warranty Information online: Data Center \\
\hline
\end{tabular}




\begin{tabular}{|c|c|}
\hline State & Reporting Requirements \\
\hline Georgia & $\begin{array}{l}\text { Monthly Reports: Passenger Trip Cost, Mileage, Ridership, Operating Revenue } \\
\text { and Expenses, and Days in Service }\end{array}$ \\
\hline Hawaii & $\begin{array}{l}\text { Operating Records: Ridership, Trip Destination, Passenger Characteristics, } \\
\text { Accidents, and Incidents / Quarterly Vehicle Report / Annual Vehicle Report / } \\
\text { Annual Performance Measure Report for Gaps in Service and Ridership }\end{array}$ \\
\hline Idaho & Annual Financial Status Report / Annual Project Report \\
\hline Illinois & $\begin{array}{l}\text { Vehicle and Equipment Control Records: Description, ID\#, Funding Source, } \\
\text { Title Holder, Federal Participation, Physical Location, Current Use, and } \\
\text { Condition }\end{array}$ \\
\hline Indiana & $\begin{array}{l}\text { Annual Vehicle Report distributed by INDOT for completion: Ridership, } \\
\text { Operating, and Financial Information }\end{array}$ \\
\hline Iowa & $\begin{array}{l}\text { Quarterly and Year-End Statistical Reports / Annual Status Report / Annual } \\
\text { Odometer Report }\end{array}$ \\
\hline Kansas & $\begin{array}{l}\text { Monthly: Ridership, Expenditure, and DBE Reports / Annual Vehicle } \\
\text { Inspections }\end{array}$ \\
\hline Kentucky & $\begin{array}{l}\text { Quarterly Vehicle Utilization Reports: Ridership, Revenue, Expenses, Vehicle } \\
\text { and Equipment Management }\end{array}$ \\
\hline Louisiana & $\begin{array}{l}\text { Loss, Damage, or Theft of an FTA-funded vehicle must be reported } \\
\text { immediately / Monthly Vehicle Maintenance Expense Record / Annual } \\
\text { Compliance Review Questionnaire / Monthly Vehicle Trip Summary Log }\end{array}$ \\
\hline Maine & $\begin{array}{l}\text { Gaps in Service Filled / Ridership / Annual Status Report / Milestone Progress } \\
\text { Report (MPR) / Program Measures Report }\end{array}$ \\
\hline Maryland & No reference to reporting requirements \\
\hline Massachusetts & Maintenance Records / Accidents \\
\hline Michigan & Detailed data on service and vehicle information \\
\hline Minnesota & $\begin{array}{l}\text { Quarterly: Actual Rides by Type of Rider and Each Vehicle Aggregate Actual } \\
\text { One-Way Trips }\end{array}$ \\
\hline Mississippi & Monthly Report for each vehicle / Six-Month Report \\
\hline Missouri & $\begin{array}{l}\text { Inform MoDOT of any accident or vehicle beyond useful life due to high } \\
\text { mileage or poor overall condition / Calendar Year for Each Vehicle: Odometer, } \\
\text { Miles Driven, One-Way Disabled Trips, One-Way Elderly Trips, Vehicle } \\
\text { Expenses (including administration) for Year, New Lease Agreements, and } \\
\text { Counties Served }\end{array}$ \\
\hline Montana & $\begin{array}{l}\text { Quarterly Report: Operations, Ridership, Performance, and Financial Costs / } \\
\text { Complete Daily Reports }\end{array}$ \\
\hline Nebraska & $\begin{array}{l}\text { Monthly Vehicle Usage Report, including Vehicle Maintenance and Vehicle } \\
\text { Maintenance Costs }\end{array}$ \\
\hline Nevada & Report all collisions within 24 hours \\
\hline New Hampshire & $\begin{array}{l}\text { Quarterly: Costs, Revenues, Service Hours, Miles, Passenger Trips, and } \\
\text { Accident Reports }\end{array}$ \\
\hline
\end{tabular}




\begin{tabular}{|c|c|}
\hline State & Reporting Requirements \\
\hline New Jersey & Quarterly: Ridership, Usage, Mileage, Repair and Maintenance Costs \\
\hline New Mexico & $\begin{array}{l}\text { Federal Financial Report / Annual Program Status Report / Quarterly Narrative } \\
\text { Report of Program Activities / Quarterly Performance Report of Program } \\
\text { Activities / Quarterly Performance Report detailing: Costs, Revenues, Service } \\
\text { Hours and Miles, Passenger Trips, and Accidents }\end{array}$ \\
\hline New York & $\begin{array}{l}\text { Mandatory Semi-annual Report Form / Voluntary Forms: Passenger Record } \\
\text { Form / Vehicle Daily Report Form / Vehicle Daily Trip Record Form / Vehicle } \\
\text { Repair Form }\end{array}$ \\
\hline North Carolina & $\begin{array}{l}\text { Pre-trip and Post-trip Inspection requirement / Report service accidents within } \\
48 \text { hours / Operating Statistics (OPSTATS) Report (Excel data tracking form) }\end{array}$ \\
\hline North Dakota & $\begin{array}{l}\text { Annually: Revenue, Sources of Revenue, Operating Costs, Capital Costs, Fleet } \\
\text { Size by Type, Revenue Vehicle Miles, and Ridership }\end{array}$ \\
\hline Ohio & $\begin{array}{l}\text { Semi-annual Reports for each vehicle: Odometer Reading, Total Elderly } \\
\text { Passenger Trips, Total Disabled Passenger Trips, Total Trips for Other } \\
\text { Passengers, Total Number of Unduplicated Elderly and Disabled Trips, Total } \\
\text { Vehicle Maintenance Costs, Days in Use, and Accidents during period }\end{array}$ \\
\hline Oklahoma & No reference to reporting requirements \\
\hline Oregon & $\begin{array}{l}\text { Fiscal Performance: Number of Rides, Hours, Miles, Senior and Disabled } \\
\text { Passenger Counts / Quarterly Revenues and Expenditures / Local } \\
\text { Contributions and Source / Vehicle Procurement Status Reports / Special } \\
\text { Purpose Reports / Vehicle Out of Service More Than } 90 \text { Days }\end{array}$ \\
\hline Pennsylvania & $\begin{array}{l}\text { Annual Vehicle Use Report / Number of One-Way Passenger Trips and Number } \\
\text { of Clients Eligible to Receive Services / Civil Rights Report / PM Report }\end{array}$ \\
\hline Rhode Island & $\begin{array}{l}\text { Quarterly Project Activity and Revenue and Expenditures / Annual Audit of } \\
\text { Funds Expended }\end{array}$ \\
\hline South Carolina & $\begin{array}{l}\text { Maintain Records: Rebuilds, Repairs, PMI Report, Daily Vehicle Condition, and } \\
\text { Work Orders }\end{array}$ \\
\hline South Dakota & $\begin{array}{l}\text { Annual Vehicle Monitoring (may be required to submit more frequently): } \\
\text { Operating Characteristics, Ridership, and Trip Purpose }\end{array}$ \\
\hline Tennessee & $\begin{array}{l}\text { Vehicle Out of Service More Than } 30 \text { Days (requires written notification) / } \\
\text { Annual Program Status Report }\end{array}$ \\
\hline Texas & $\begin{array}{l}\text { Extraordinary change in vehicle or its equipment / Maintain Records: Trip } \\
\text { Logs, Driver Safety, Insurance, Regular and Major Maintenance, Repairs, and } \\
\text { Operating Budget / Quarterly Reports }\end{array}$ \\
\hline Utah & $\begin{array}{l}\text { Quarterly and Monthly Financial and Operating Data Reports / Annual } \\
\text { Certification and Assurance Report / Vehicle Surveillance Inspection Report / } \\
\text { Maintenance Report / Vehicle Use Report }\end{array}$ \\
\hline Vermont & $\begin{array}{l}\text { Annual Vehicle Report / Quarterly Milestone Progress Reports (MPR) and } \\
\text { Financial Reports / Monthly Ridership and Expenditure Reports / Annual } \\
\text { Vehicle Inventory Reports / Annual Vehicle Maintenance Certification }\end{array}$ \\
\hline Virginia & $\begin{array}{l}\text { Loss or Damage / Maintain File on Each Vehicle: Daily Logs, Inspection } \\
\text { Checklist, and Repair Records }\end{array}$ \\
\hline
\end{tabular}




\section{Table 21 Reporting Requirements continued}

\begin{tabular}{|c|c|}
\hline State & Reporting Requirements \\
\hline Washington & Annual Asset Inventory \\
\hline West Virginia & $\begin{array}{l}\text { Complete Section } 5310 \text { Monthly Report online: Passengers Carried, Miles } \\
\text { Traveled, and Maintenance Costs }\end{array}$ \\
\hline Wisconsin & $\begin{array}{l}\text { Semi-annual Reports of Operating Data / Annual October Ridership Report / } \\
\text { Annual Vehicle Certification }\end{array}$ \\
\hline Wyoming & $\begin{array}{l}\text { Up-to-Date Maintenance Records for Each Vehicle: Vehicle Repairs (date and } \\
\text { mileage) / PM Reports (date and mileage) / Daily Vehicle Inspection Reports } \\
\text { (pre-trip inspections that include date and mileage) }\end{array}$ \\
\hline District of Columbia & $\begin{array}{l}\text { Quarterly Program Status Reports: Program Measures and Maintenance } \\
\text { Records }\end{array}$ \\
\hline
\end{tabular}

\section{Other State 5310 Comparison Findings}

The Department of Transportation is the designated Section 5310 administrator in Florida as in all other states, including the District of Columbia, with the exception of Georgia, Oklahoma, and Maryland. Assignment of program administration to the state's public transit office was most common, followed by assignment to the state department of transportation. Florida's Public Transit Office serves as the program administrator for Section 5310 funds within Florida.

A total of 35 states require subrecipients to follow a federal/local match of $80 / 20$, while the remaining 16 states require compliance with a maximum federal match of 80 percent, but have established a different percent for the local match. States used a variety of means to impact the local match, including an add-on of one percent of the total procurement cost of capital equipment, reduction of the local match through the use of toll credits, a set cap for procurement costs with the subrecipient responsible for any amount in excess of the cap, and covering a portion or the entire amount of the local match, depending on availability of funds. Florida is one of 16 states that provide subrecipients with a reduced local match $(10 \%)$.

More than half of the states acknowledged use of state administrative expenses at the maximum allowable rate of 10 percent, primarily for program administration costs, the procurement process, and training.

The majority of vehicle procurements are processed at the state level, often through use of a state contract, and while many states do allow subrecipients to establish their own procurement processes, subrecipients are most always subject to state oversight and approval prior to actual procurement. Georgia restricts the use of Section 5310 funds to the purchase of service rather than the purchase of vehicles. Florida appears to be the only state that requires a second level of safety testing for compliance with established FDOT Crash and Safety Testing Standards; mean comparison tests of mileage and useful life showed that vehicles administered under Florida's TRIPS program have a longer useful life when compared to the out-of-state sample. In Iowa, subrecipients are given the option to procure capital items themselves, join with their peers in consortium procurements, or to 
defer to the state in a statewide procurement. In Vermont, all Section 5310 vehicle procurements are completed by a designated 5311 transportation organization.

In a majority of the states, the procurement agency conducts and certifies the pre-award audit. Some agencies provide inspectors to review vehicles on the assembly line, while others have a resident inspector present at the manufacturer's final assembly location throughout the manufacturing process, and others conduct in-plant vehicle inspections when the procurement threshold is below federal mandates. Pursuant to the Florida TRIPS contract, the dealer is required to submit weekly status reports to the TRIPS Database Center, which tracks the progress of each individual vehicle through the procurement and production process. The report is coordinated with the manufacturer's report. In addition, the vehicle manufacturer's compliance is continually monitored by contracted line inspectors at each vehicle production site.

While less than half of post-delivery audits are performed and certified by the procurement agency, most post-delivery audits generally include a review of Buy America and FMVSS compliance as part of a site visit that consists of a complete visual inspection and road test to demonstrate that the vehicle meets the contract specifications. In Florida, all vehicles must be delivered to the Springhill Bus Testing and Inspection Facility (SBTIF) located in Tallahassee, Florida, for an inspection scheduled by the TRIPS manager. Deficiencies noted must be completed before delivery to a subrecipient. The dealer is required to submit weekly status reports to the TRIPS Database Center, which tracks the progress of each individual vehicle through the procurement and production process, from receipt of order through delivery and acceptance of each individual vehicle by the agency. The report is coordinated with the manufacturer's report. The dealer must also provide a vehicle orientation with each vehicle delivered to an agency.

Subrecipients in most states have a written maintenance plan or documented maintenance procedures, with the exception of Delaware and Rhode Island. Delaware provides vehicle maintenance at statewide locations. Rhode Island maintains all vehicles purchased with FTA funding for the useful life of the vehicle; however, the cost of maintenance is the responsibility of the subrecipient. Preventive Maintenance Plans range from a requirement that the subrecipient meet at least the minimum OEM recommendations for maintenance and preventive maintenance to an official state Preventive Maintenance Manual, similar to that used in Florida. Nevada has developed a software maintenance plan for subrecipients' use, and Rhode Island created a centralized Preventive Maintenance Plan, specifically for use within its centralized maintenance program.

Most compliance reviews and/or inspections are conducted every two to three years, as is the case in Florida. Several states conduct a portion of compliance reviews each year. Delaware inspects all vehicles at Delaware's statewide maintenance facilities.

Quarterly reporting is required in more than a third of the states, while a fifth of the states require some type of monthly reporting. Florida, Alabama, and West Virginia have incorporated online reporting, and North Carolina has established an Operating Statistics 
(OPSTATS) Report that enables subrecipients to identify trends through use of an Excel data tracking form. 


\section{Chapter 5 \\ Findings and Recommendations}

\section{Findings}

The TRIPS program handled over $\$ 100$ million in transit vehicle purchases from 2007 to 2011 , and on average vehicles purchased through the program were $\$ 1,275$ less expensive than similar vehicles nationally. This lower cost of acquisition for the majority of the vehicles purchased translates into $\$ 409,275$ savings for the years 2010 and 2011 , or in excess of $\$ 204,000$ per year.

Cutaway vehicles purchased under the 5310 program through TRIPS have come down in acquisition cost from the $\$ 70,000$ to $\$ 80,000$ range in 2007 and 2008 to less than $\$ 64,000$ by 2011 . The majority of these purchase orders were for "Cutaway" or "Standard Cutaway" vehicles. For these vehicles the cost has ranged on average from a high of over $\$ 84,000$ to $\$ 63,369$ in 2011.

Since 2007, the average cost to repair collision damage for a DR vehicle in Florida has been lower than the national average. During the 2006 through 2011 period, Florida's collision costs were approximately $\$ 600$ lower for each incident. This may not be solely due to increased vehicle integrity afforded by the stringent TRIPS vehicle safety specifications; however, the data show lower costs of repair. Annualized, this translates into an estimated annual cost avoided of $\$ 23,262.52$.

Passenger injury rates were lower for Florida's DR service (a subset of the TRIPS vehicles) than the national rates based on NTD data. The injury rate was, on average, 16.53 percent lower for passengers in Florida than for the U.S. for the study period. If the passenger injury rate for Florida's DR service users was the same as the national average, there would be additional injuries. Using NHTSA figures for the cost per injury, an annual cost avoidance of $\$ 797,237$ is calculated.

There is clear evidence of aggressive pre-delivery and warranty tracking and issue resolution. More than 4,600 issues were documented requiring attention and resolved for TRIPS vehicles from 2008 to 2011.

TRIPS relieves small and large agencies of the administrative burdens required in the development of technical specifications and competitive procurement practices, and provides them with the opportunity to take advantage of TRIPS contracts that incorporate sound technical and safety specifications, enhanced vehicle inspection practices, mandated dealer coordination, training, technical assistance, and extended warranties.

The review of the five FDOT district inspection reports revealed that 34 percent of the TRIPS fleet has been in service for more than five years and 3.3 percent of the vehicles had recorded mileage of over 150,000 miles. Based on the review of these reports, the findings support that, in terms of performance data, the vehicles show extensive service well beyond their projected useful life. A comparison with other states' useful life requirement for 
vehicles purchased with Section 5310 funds shows that Florida's TRIPS vehicles are required to achieve a longer useful life.

On an annual basis, the program costs for CUTR to manage and operate the TRIPS program have been stable at $\$ 540,000$ per year with the exception of an additional $\$ 175,000$ in grants in FY 2009-2010 and FY 2010-2011 because of the increased activity resulting from ARRA funding. The average cost to FDOT for the 2007 through 2011 study period was $\$ 586,000$. This translates into a cost per unit of $\$ 2,395.75$.

FTA and FDOT cap program administration costs at 10 percent for the 5310 program, and CUTR's cost represents 3.25 percent of the average vehicle cost for all vehicles reported in the PO database for the 2007 through 2011 period.

Florida is one of only 16 states that provide subrecipients with a reduced local match (10\%) for the purchase of transit vehicles under the Section 5310 program, and Florida appears to be the only state that requires a second level of safety testing for compliance with established FDOT Crash and Safety Testing Standards.

Mean comparison tests of mileage and useful life showed that vehicles administered under Florida's TRIPS program have a longer useful life when compared to the out-of-state sample.

Adding all of the calculated costs avoided based on the performance of DR vehicles in Florida, their safety record and acquisition costs, and deducting the program administrative costs yields an estimated $\$ 408,000$ net annual benefit to the state.

\section{Recommendations}

To conduct future analysis of the benefits and costs associated with the TRIPS program, maintenance and repair data throughout the life of each vehicle would be necessary. Expanded data collection could be achieved through the expansion of the TRIPS database, including regular entry of vehicle mileage, recording the date when a situation occurs, and including specific details surrounding maintenance and/or repairs throughout the service life of the vehicles.

As shown in Figure 8, the TRIPS database already allows entering information under the Inspection Agency main page. After logging on to the database, dealers and inspection agencies can report any issues affecting a vehicle. Currently, this information is generally entered when conducting pre- and post-delivery inspections. CUTR suggests that in addition to improving data reporting accuracy by including mileage, repair dates, and maintenance details, the Situation and Action tables include common headers to trace vehicles back to their initial PO numbers. An additional header linked to the PO table to record the VIN once the vehicle has been produced would allow linking the PO, Situation, and Action Taken tables in the SQL server database to better integrate information. 


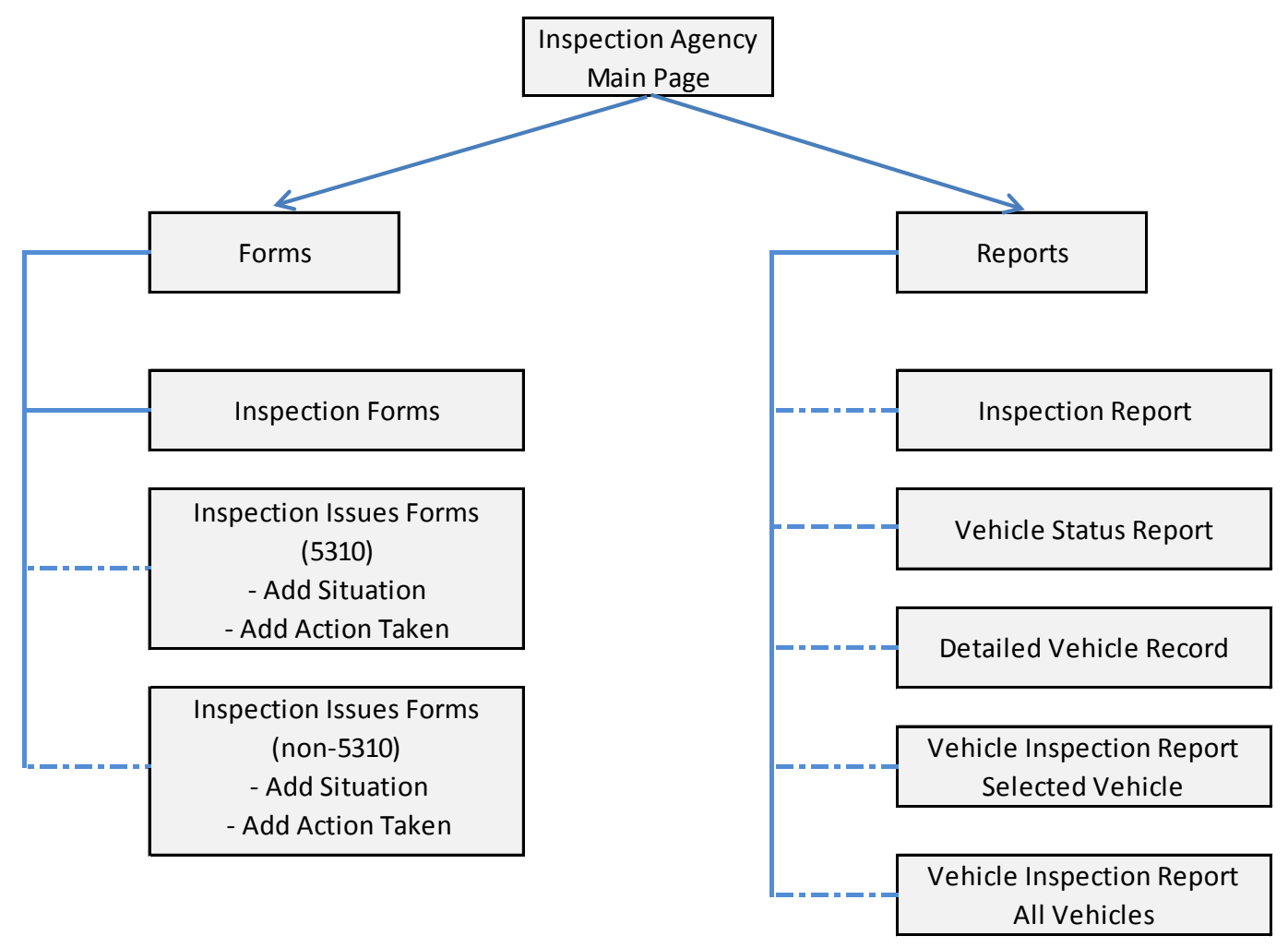

Figure 8 TRIPS Inspection Agency Webpage Overview

Researchers recommend extending the Transit Agency webpage to allow quarterly vehicle status reporting, as well as reporting of specific mechanical issues that occur once the vehicle has passed post-production inspection and enters operation. Figure 9 reports the recommended improvements to the Transit Agency webpage and underlying SQL database to allow collecting information that can subsequently be used for analysis. Quarterly reporting should ideally start once the vehicle enters operation and should occur on a regular basis for all vehicles purchased by each subrecipient. The collection of this information can be used to compare TRIPS vehicle performance with vehicles purchased by transit agencies by other means, or to compare TRIPS vehicles with similar vehicle fleets in sample out-of-state locations. 


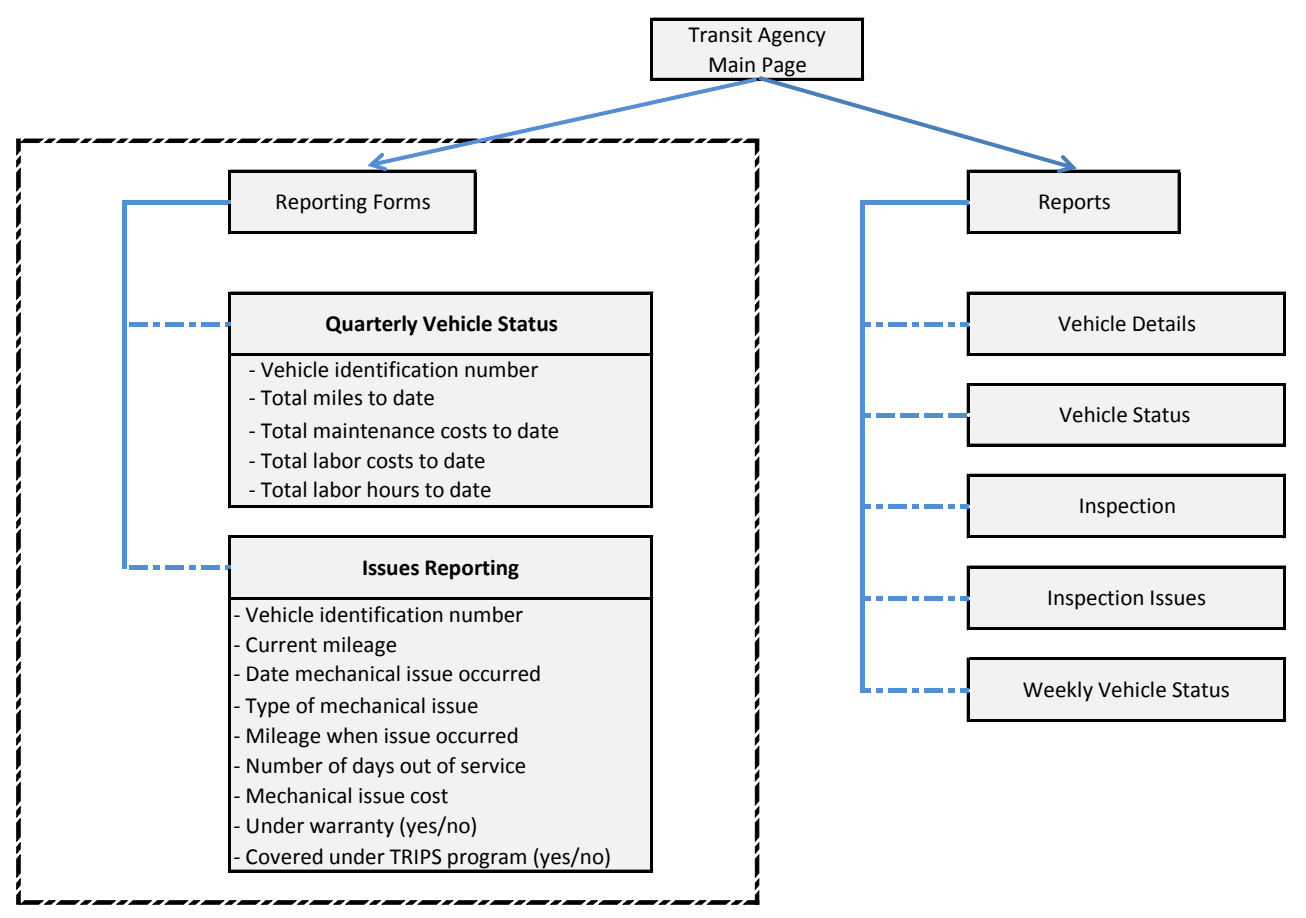

Figure 9 Recommended Modifications to Transit Agency TRIPS Webpage

While the administration and structure of Florida's Section 5310 program mirrors the majority of other states' Section 5310 programs, Florida does provide a significant degree of assistance to subrecipients in meeting local match requirements, and through enhanced vehicle specifications ensures not only a secondary level of crash and safety standards, but also vehicles that exceed the useful life of an out-of-state sample of similar vehicles. The inspection of all vehicles at the Springhill Bus Testing and Inspection Facility prior to delivery to subrecipients, combined with a comprehensive warranty recovery program, provides Florida's subrecipients with safe, heavy-duty, and well-designed vehicles for their Section 5310 programs.

Many agencies maintain regular quarterly reporting of detailed vehicle maintenance and cost information that could be used in the cost-benefit assessment of Florida's TRIPS program in the future. 


\section{Appendix A}

Section 5310 State Management Plans and Application Manuals

Alabama Department of Transportation, Bureau of Modal Programs, Transit Section: Elderly Individuals and Individuals with Disabilities Program (Section 5310), Statewide Competitive Grant for Fiscal Year 2011

Alaska State Management Plan, Alaska Department of Transportation \& Public Facilities, State Transit Office, 2010

Arizona Department of Transportation, Multimodal Planning Division, Public Transportation State Management Plan, Parts I and II, Effective: October 1, 2008

Arkansas State Highway and Transportation Department, 2013 Application: Section 5310, Elderly Persons and Persons with Disabilities Program for the Capital Assistance Program, January 2012

California Department of Transportation, Division of Mass Transportation, Caltrans State Management Plan Federal Transit Program, September 2011

Colorado Department of Transportation State Management Plan, Spring 2009

Connecticut Department of Transportation, Application for Capital Assistance for Private Nonprofit Organizations and Eligible Local Public Bodies to Provide Transportation Services for Elderly Persons and Persons with Disabilities, Federal Transit Administration's Section 5310 Program, Federal Fiscal Year 2012 Grant Cycle

Delaware Transit Corporation FTA Section 5310 Program, FY 2012, Applicant Information Guide

District of Columbia Management Plan, Section 5310 Capital Assistance Program, District Department of Transportation, Mass Transit Administration, November 2009

Florida Department of Transportation, Public Transit Office, 2012 U.S.C. Section 5310 Capital Assistance Application Manual

Georgia Department of Human Services, Georgia State Management Plan and Application Package for Transportation of Elderly Persons and Persons with Disabilities, SFY 2010

State of Hawaii Department of Transportation, Statewide Transportation Planning Office, Capital Assistance for the Transportation of the Elderly and Disabled, FY 2012

Idaho Transportation Department State Management Plan, Formula Programs, Federal

Transit Administration, October 2009

Illinois Department of Transportation, 5310/5311 Grant Management Manual, 2012

Indiana Department of Transportation, Transit Office, Section 5310 State Management Plan, May 2009

Office of Public Transit, Iowa Department of Transportation, Iowa State Management Plan

for Administration of Funding and Grants under Programs from the Federal Transit

Administration, July 2011

Kansas Department of Transportation, Office of Public Transportation, State Management Plan for Kansas Public Transportation Program, Rev. 4/08

Kentucky Transportation Cabinet (KYTC) Office of Transportation Deliver (OTD), KY State Management Plan, June 16, 2011

State of Louisiana Department of Transportation and Development, Public Transportation Section, 2012, Application Procedures Manual for the Section 5310 Elderly Individuals and Individuals with Disabilities Program

State of Maine, Maine DOT, State Management Plan for the United States Department of Transportation, Federal Transit Administration, Public Transportation Programs, July 2011

Maryland Department of Transportation, Maryland Transit Administration, Office of Local Transit Support, Application Forms for Federal Capital Grants Under Section 5310, 12/2010 Massachusetts Department of Transportation, MassDOT, Rail and Transit Division, MassDOT Community Transit Grant Program, Single Grant Application, State Fiscal Year 2013 
State of Michigan Management Plan for Funding Under Sections 5310, 5311, 5316, and 5317 of the Federal Public Transportation Act, February 19, 2008

Minnesota Department of Transportation, Office of Transit, State Management Plan, CY 2012 Management Plan Instructions, Greater Minnesota Public Transit Systems

Mississippi Department of Transportation, Public Transit Division, State Management Plan for Federal Transit Administration Funded Transportation Program, July 2011

Missouri Department of Transportation, Section 5310, Elderly and Persons with Disabilities Program, State Management Plan (SMP), October 2010

Montana State Management Plan, Montana MDT, Department of Transportation, Transit Section, Amended 2009

Nebraska Department of Roads, Planning and Administration, Rail and Public Transportation Division, Nebraska State Management Plan for Public Transportation in Rural and Small Urban Areas, July 2009

State of Nevada, Nevada Department of Transportation, State Management Plan, Federal Transit Administration Programs for 5303, 5304, 5307, 5309, 5310, 5316, and 5317 Rural and Small Urban Areas of Nevada, July 2008

New Hampshire Department of Transportation, Public Transportation Programs (Section 5310, 5311, 5316, 5317), State Management Plan, 2010

State of New Jersey, State Management Plan, Section 5310 Program, The Elderly Individuals and People with Disabilities Program, February 2012

New Mexico Department of Transportation, Transit and Rail Division, New Mexico State Management Plan for the Administration of Federal Transit Grants, April 2010

State of New York, Department of Transportation, FFY 2012 FTA Section 5310 Program, Application for Federal Funding Assistance, 2012

North Carolina Department of Transportation, Public Transportation Division, State Management Plan for Title 49 U.S.C. Sections 5310, 5311, 5316, and 5317, February 2012

North Dakota Department of Transportation (NDDOT), Transit, State Management Plan, May 2011

State of Ohio, Ohio Department of Transportation, Office of Transit, Management Plan for Public Transportation in Nonurbanized Areas

State of Ohio, Ohio Department of Transportation, Office of Transit, Management Plan for Elderly Individuals and Individuals with Disabilities FTA Section 5310 Program, 2009 Oklahoma Department of Human Services, Aging Services Division: www.okdhs.org Oregon Department of Transportation, Public Transit Division, State Management Plan for Public Transportation Programs, 2009

Pennsylvania Department of Transportation, Pennsylvania State Management Plan, Federal Programs: 5310, 5311, 5316 \& 5317, Bureau of Public Transportation, March 2100 Rhode Island Public Transit Authority, Rhode Island Management Plan, Federal Transit Administration Grant Programs, January 2009

South Carolina Department of Transportation, Office of Public Transit, Division of Intermodal and Freight Programs, Federal Transit Administration Programs, State Management Plan, November 2010

South Dakota Department of Transportation, Division of Finance and Management, Office of Local Transportation Programs, South Dakota Management Plan for the Section 5310, 5316, and 5317 Programs, July 2011

Tennessee Department of Transportation, Division of Multimodal Transportation Resources, Federal Transit Administration Programs, State Management Plan, November 2011

Texas Department of Transportation, Public Transportation Division, Section 5310 Elderly Individuals and Individuals with Disabilities, Application Information Guide, 2011

Utah Department of Transportation, Public Transit Team, UDOT State Management Plan, Federal Transit Grant Programs, February 2010

VTrans, Operations Division, Public Transit Section, Vermont State Management Plan, 2008 


\begin{tabular}{|l|}
\hline Virginia Department of Rail and Public Transportation (DRPT), Public Transportation and \\
Transportation Demand Grant Program Application Guidance, 2012 \\
\hline Washington State, Public Transportation Division, State Management Plan for Federal \\
Transit Administration Public Transportation Programs, December 2011 \\
\hline West Virginia Department of Transportation, Division of Public Transit, West Virginia Section \\
5310 Elderly Individuals and Individuals with Disabilities Program, State Management Plan, \\
March 2010 \\
\hline Wisconsin Department of Transportation, Bureau of Transit, Local Roads, Railroads \& \\
Harbors, Section 5310 Application, Elderly \& Disabled Transportation Capital Assistance \\
Program, 2012 \\
\hline Wyoming Department of Transportation, Office of Local Government Coordination - Transit, \\
State Management Plan for: Federal Transportation Administration of Public Transportation \\
Programs, February 2010 \\
\hline
\end{tabular}




\section{Appendix B}

Please click the Data Request tab and enter information on each of your vehicles you are currently operating.

To facilitate filling in information, some cells have a drop-down list where you can select pre-filled options. For

each vehicle, please enter the VIN number so that we can match it to the vehicle under the TRIPS program (if

the vehicle was purchased under this program). If you need assistance, please contact Sisinnio Concas.

Thank You!

\begin{tabular}{|c|c|c|c|c|c|c|c|c|c|c|c|c|c|c|c|c|c|c|c|c|c|}
\hline $\begin{array}{l}\text { Aegency } \\
\text { Name }\end{array}$ & $\begin{array}{l}\text { venicle } \\
\text { Identification } \\
\text { Number }\end{array}$ & $\begin{array}{l}\text { vehicle } \\
\text { Manurafturer } \\
\text { choose from list) }\end{array}$ & $\begin{array}{c}\text { Vehicle } \\
\text { Type } \\
\text { (choose } \\
\text { from list) }\end{array}$ & $\begin{array}{l}\text { Chassis } \\
\text { Make }\end{array}$ & $\begin{array}{l}\text { chassis } \\
\text { Model } \\
\text { lctose } \\
\text { from list) }\end{array}$ & $\begin{array}{c}\text { Engine } \\
\text { Type } \\
\text { (choose } \\
\text { from list) }\end{array}$ & {$\left[\begin{array}{c}\text { size } \\
\text { (feet) }\end{array} \mid\right.$} & $\begin{array}{l}\text { Seating } \\
\text { Capacity }\end{array}$ & \begin{tabular}{|c|c} 
Date \\
Purchased
\end{tabular} & $\begin{array}{c}\text { Date eut } \\
\text { into } \\
\text { Service }\end{array}$ & $\begin{array}{l}\text { Total } \\
\text { Purchase } \\
\text { cost(s) }\end{array}$ & $\begin{array}{c}\text { current } \\
\text { Mileage }\end{array}$ & $\begin{array}{c}\text { Date } \\
\text { Mechanical } \\
\text { Issue } \\
\text { Occurred }\end{array}$ & $\begin{array}{c}\text { Type of } \\
\text { Mechanical } \\
\text { Issue }\end{array}$ & $\begin{array}{c}\text { Mileage } \\
\text { when ssue } \\
\text { Occurred }\end{array}$ & $\begin{array}{l}\text { Mechanical } \\
\text { Issue cost }\end{array}$ & \begin{tabular}{|} 
Under \\
Warranty \\
chboose \\
from list)
\end{tabular} & $\begin{array}{l}\text { Covered under } \\
\text { Trlps Program } \\
\text { (choses from } \\
\text { list) }\end{array}$ & \begin{tabular}{|} 
Total \\
Maintenance \\
Costs to Date
\end{tabular} & $\begin{array}{c}\text { Total labor } \\
\text { Costs to } \\
\text { Date }\end{array}$ & $\begin{array}{c}\text { Totat Labor } \\
\text { Hours to } \\
\text { Date }\end{array}$ \\
\hline \multicolumn{22}{|l|}{\begin{tabular}{|l|} 
Agency A \\
Agency A \\
\end{tabular}} \\
\hline \multicolumn{22}{|l|}{\begin{tabular}{|l|} 
Agency $A$ \\
ABency $A$ \\
Aanency B
\end{tabular}} \\
\hline \multicolumn{22}{|l|}{\begin{tabular}{|l|l|} 
Agency B \\
$A \operatorname{Agency}$ B \\
\end{tabular}} \\
\hline \multicolumn{22}{|l|}{\begin{tabular}{|l|} 
ABency B \\
Bency \\
\end{tabular}} \\
\hline \multicolumn{22}{|l|}{\begin{tabular}{|l|} 
Agency B \\
Agency C \\
Aaencoc
\end{tabular}} \\
\hline \multicolumn{22}{|l|}{\begin{tabular}{|l|} 
Agenency $C$ \\
Agency $C$ \\
\end{tabular}} \\
\hline \multicolumn{22}{|l|}{ 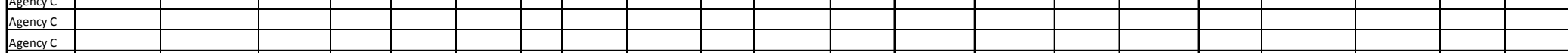 } \\
\hline \multicolumn{22}{|l|}{\begin{tabular}{|l|}
$A \operatorname{sen} c y$ \\
$A \operatorname{egency}$ \\
\end{tabular}} \\
\hline \multicolumn{22}{|l|}{ 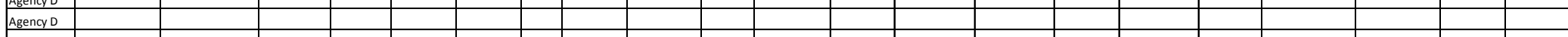 } \\
\hline \multirow{2}{*}{\multicolumn{22}{|c|}{\begin{tabular}{|l|} 
Agency D \\
Agency D \\
\end{tabular}}} \\
\hline \\
\hline & \multicolumn{21}{|c|}{\begin{tabular}{|l|} 
Agency E \\
Agency
\end{tabular}} \\
\hline \multicolumn{22}{|l|}{\begin{tabular}{|l|} 
Agency E \\
Agency \\
Bat
\end{tabular}} \\
\hline \multicolumn{22}{|l|}{\begin{tabular}{|l|}
$A g e n c y)$ \\
$A g e n c y F$ \\
\end{tabular}} \\
\hline \multicolumn{22}{|l|}{\begin{tabular}{|l} 
Agency \\
Aasency F
\end{tabular}} \\
\hline \multicolumn{22}{|l|}{\begin{tabular}{|l|} 
Agency F \\
Agency
\end{tabular}} \\
\hline \multicolumn{22}{|l|}{$\mid$} \\
\hline \multicolumn{22}{|l|}{$\operatorname{Ag} \operatorname{sen} r y$} \\
\hline \multicolumn{22}{|l|}{\begin{tabular}{|l|}
$A \operatorname{senc} c y$ \\
$A \operatorname{senncy} G$ \\
\end{tabular}} \\
\hline \multicolumn{22}{|l|}{$\begin{array}{l}\text { Aseneryo } \\
\text { Agency }\end{array}$} \\
\hline \multirow{2}{*}{\multicolumn{22}{|c|}{\begin{tabular}{|l|} 
Agency \\
Aagency
\end{tabular}}} \\
\hline & & & & & & & & & & & & & & & & & & & & & \\
\hline & & & & & & & & & & & & & & & & & & & & & \\
\hline
\end{tabular}

